\title{
Introduction to the Second Edition: Contextualizing the Nueva corónica y buen gobierno
}

In the years following the initial publication of this monograph, Felipe Guaman Poma and his Nueva corónica y buen gobierno have been the object of increasing focus from a variety of disciplinary perspectives. His work remains a unique source of information on the pre-Columbian Andes, and the broad range of inquiries generated in the fields of ethnohistory, history of art, linguistics, and literary and cultural history testify to Guaman Poma's key role in facilitating our understanding of the Andean and Spanish colonial pasts. As the variety and significance of scholarship based on the Nueva corónica y buen gobierno increase, it is useful to address some basic questions: Who was Guaman Poma? How does information about his identity relate to the work he produced? The chronicle/treatise exhibits an extraordinary consistency of information and outlook from start to finish, and it coincides not only with what Guaman Poma says about himself in his twelve-hundred-page letter to the king but also with what we learn about him from recently retrieved and long known external documentary sources. Coordinating this documentation with his chronicle allows us to reconfigure the elements of his biography and to better understand its relationship to the conceptualization of his work. The purpose of this essay is to offer a fuller context for reading the Nueva corónica y buen gobierno as well as the monograph that is being republished on this occasion.

\section{Guaman Poma in the Documentary Record}

External documents verifying Guaman Poma's existence and experience began to emerge in the late 1930s, after the 1936 facsimile publica- 
tion in Paris of the autograph manuscript (GKS, 2232, $4^{\circ}$, Royal Library of Copenhagen). The first was Rodolfo Salazar's 1938 publication of a document in which Guaman Poma served as an interpreter and witness in a November 1595 transaction whereby land claims of the heirs of the kuraka of Lurinsaya, Don Pedro Suyro, were upheld in the jurisdiction of Huamanga (Salazar in Varallanos 1979:210-211). Appearing as assistant or secretary to the natives' appointed representative (protector de naturales) Amador de Valdepeña, Guaman Poma signed his name to the document, dated 20 November 1595, as "Don Phelipe Guaman Poma," indicating the noble social status by which he was recognized (Varallanos 1979:31,38n9). The next major event was Guillermo Lohmann Villena's (1945:325-327) publication of a crucial documentary find in the Archives of the Indies, Seville, Spain; in this 14 February 1615 letter to Felipe III the chronicer introduced himself and his completed work to the monarch and expressed the desire that the king request and read it. He added that the Marqués de Salinas, current president of the Council of the Indies, could give the king fuller information about him from the time that the Marqués (Don Luis de Velasco) had served as viceroy of Peru.

In 1952 and 1954, the Reverend Elías Prado Tello published, respectively, one of Guaman Poma's petitions and three drawings, obviously copies of ones originally drawn by Guaman Poma, contained in the dossier pertaining to the lands of Chiara in the area of Chupas that the Monsignor Prado Tello would later publish in full in 1991. In 1955, Fray Pedro Mañaricúa published the criminal sentence pronounced against Guaman Poma in the year 1600. Drawing together these little known publications, Edmundo Guillén Guillén (1969) rightly argued that their cumulative effect provided sensational new findings about the life of Guaman Poma.

Evidence continued to accumulate in the 1970s when Guaman Poma's participation in confirmation of land title proceedings revealed, as had the 1938 documentary discovery mentioned above, that Guaman Poma served once again as a witness and interpreter and that once again, by the appearance of the title "don" before his name, he was recognized as a cacique or person of elite status. One such document, dated 16 September 1594, was found and studied by Juan C. Zorrilla (1977:50n1) and Steve J. Stern (1978:226). Another, discovered and transcribed much more recently by Nelson Pereyra Chávez (1997:261-270), shows that on 10 
September 1594 Guaman Poma was ordered to inspect the lands of Totora Pampa and Rumichaca of the city of Huamanga and mark their boundaries, confirming them to the possession of Doña Catalina Patta. On 20 September 1594, having made his inspection and set and confirmed the land's boundaries, he issued his report in Huamanga. A major publication of the 1970s was Zorrilla's (1977) transcription of the Compulsa Ayacucho, which in thirty-two folios revealed the conflicting claims of the Chachapoyas and Guaman Poma and his kin to the lands of Chiara in the valley of Chupas outside Huamanga in the 1590s. The proceedings concluded with the 1600 sentence against Guaman Poma which Mañaricúa had published in 1955.

The 1990s have been particularly fruitful in producing documentary evidence that sheds further light on Guaman Poma and his activities as they relate to the production of the work by which we know him. Elías Prado Tello and Alfredo Prado Prado's 1991 publication of the dossier of litigations concerning the lands of Chiara gives a much fuller and more detailed picture of the land-title struggles of Guaman Poma against the Chachapoyas than appears in the Compulsa Ayacucho. The Expediente Prado Tello, from which Prado Tello's 1954 publication of the three drawings had been taken, is the necessary complement to the Compulsa.

The second major advance of the 1990s has been the recovery, by Juan M. Ossio, of the lost Loyola manuscript of Fray Martín de Murúa's 1590 history of the Incas (O'Brien 1996; Ossio 1998, 1999). Once newly published, the Loyola manuscript will retrieve for our renewed scrutiny the incontrovertible evidence of Guaman Poma's artistic vocation in its association with the Mercedarian friar Martín de Murúa. More than any other documentary discoveries, the Prado Tello and Loyola manuscripts allow us to place Guaman Poma's literary and artistic achievements in the sphere of his activism as a literate litigant and his broader creative endeavors.

\section{The Production and Facsimile Reproduction of the Autograph Manuscript}

Catalogued in the Royal Library of Denmark in Copenhagen since before the original census was made of that repository's holdings in 1785, Guaman Poma's autograph manuscript, El primer nueva corónica y buen 
gobierno, was made known by Richard A. Pietschmann in 1908 and fully claimed by the world of scholarship after 1936, when Dr. Paul Rivet oversaw the facsimile publication of the manuscript by l'Institut d'Ethnologie of the University of Paris.

The Nueva corónica y buen gobierno is an artistically conceived text, and its knowledgeable and creative manipulation of European literary modes, Western Christian iconographic traditions, and Andean forms of signification render inadequate any single generic classification that might be proposed to describe it (Adorno 1979-80:8-9). The quarto size volume is made up of signatures of twelve to sixteen sheets each; the high quality paper carries throughout a watermark consisting of a Latin cross superimposed on a shield under which the initials A A and, alternatively, I A appear (Adorno 1979-80:16). Guaman Poma's expressed hope to have his "new chronicle and treatise on good government" published by King Philip III is given substance by the full complement of printing conventions he used in the preparation of his manuscript, imitating the practices of typeset books in every detail from running heads to catchwords and including a title-page annotation, intended for the prospective printer, that indicated the compositional character and length of the work by tallying the number of its sheets and folios (Adorno 1979-80:20-21). Guaman Poma used the modern system of pagination, not traditional foliation, to mark the 1,189 pages of his work, 398 of which are drawings executed by his own hand. Valerie Fraser (1996:272) has described Guaman Poma's calligraphy as "a Latinate form of cursive derived from ecclesiastical scriptorial traditions" that employs as well lettering styles that reproduce the main families of type font used in the sixteenth century (roman-italic and gothic or blackletter) and the manuscript traditions from which they were derived.

Guaman Poma's customary drafting procedure is revealed by his use of a single color of ink and its shading into another color as he dipped his pen into a new ink source. His method of composition seems to have been to draw a series of pictures for a chapter or portion of a chapter and then fill in their titles and captions at the same time as he transcribed the accompanying page of prose text. The inks he employed show today as black and brown, with several intermediate shades due to color mixing. His compositional procedure is seen most clearly on pages 862-877 of the autograph manuscript where he executes a series of drawings in black 
ink and writes the accompanying script (of titles and captions of drawings and the facing prose text) in brown-black shades that are gradually replaced by a uniform brown. He added catchwords and page numbers later, as evidenced by the use of another shade of ink and a wider-thanusual pen nib (Adorno 1979-80:17).

Guaman Poma's (1980:1074) reference to the original version of his work tells us that the autograph document in Copenhagen is a clean copy of the completed work. It is also the record of a subsequent series of additions and emendations that correct Guaman Poma's earlier oversights and reveal his deepening preoccupations. Both the main draft and all the modifications are the work of a single individual. The occasional variation in scriptorial style provides no evidence of a change in hand, and the foot-of-the-page additions exhibit a penmanship identical in its formation of letters to that found throughout the body of the manuscript. The only notable difference in handwriting style is found in the late textual additions, located at the bottom of more than one hundred twenty pages. Here the handwriting style is cramped, but this is due merely to the limited writing space the author had available and the lack of support for the heel of his hand at the edge of the bulky sewn signatures (Guaman Poma 1936:4, 5, 982, 985; see table of emendations in Adorno 1980:xlvi). The scrutiny of the formation and orientation of the letters in these late emendations reveals that they are the work of the hand that created the main body of the text.

Guaman Poma added several folios to the manuscript after the signatures were already sewn. He originally had omitted the sixth viceroy of Peru from his Buen gobierno presentation, so he added a folio containing the portrait of Fernando de Torres y Portugal as well as the standard accompanying page of prose, and then corrected the numbering on the portraits of his successors (n.n. in the autograph manuscript; Guaman Poma 1936:464 465; Guaman Poma 1980:466-467). Since this viceroy in 1586 granted the Chachapoyas the lands Guaman Poma claimed as his own in the area of Chupas outside Huamanga (see below, "Guaman Poma versus Don Domingo Jauli and the Chachapoyas"), the omission might be considered a sleight rather than an oversight, yet Guaman Poma's prose portrait of Torres as viceroy expresses unmitigated praise of his governorship (Guaman Poma 1980:467).

Other additions of new folios reflect the author's deepening concern 
for certain issues and his desire to impress their importance on Philip III. These consist of the addition of two folios to his imaginary dialogue with the king, entitled "Pregunta Su Magestad"; the addition of a single folio devoted to Guaman Poma's iconographic representation of Potosí; and that of eighteen folios, the chapter "Camina el autor," in which Guaman Poma narrates his journey to Lima to deliver his completed manuscript (Guaman Poma 1980:978-979, 1067-1068, 1104-1139). The purpose of the two new folios in the dialogue text is to advocate for the abolition of salary for priests, utilizing as salaryless exemplars the "first priest, Jesus Christ" and the "natives [naturales], Indians of Your Majesty." In the added folio about Potosí, Guaman Poma pointedly underscores the Spanish crown's dependence on the silver mine and its donation to the king by the lords of Peru. "Camina el autor" decries the suffering caused in the native communities of the valley of Huarochiri by the extirpation of idolatries campaign of Francisco de Ávila and condemns the disarray and corruption of life in the viceregal capital.

As Lohmann Villena (1945:326) first noted, the temporal references in the autograph manuscript cluster in the early seventeenth century. Apart from the year 1587, which appears in Guaman Poma's father's apocryphal letter of introduction, and a single reference to the crucial year of 1600 (Guaman Poma 1980:7, 886), Guaman Poma's mentions of dates span the years 1608 through 1615 . He uses them for two purposes. On one hand, he implicitly mentions the present date of his writing when calculating the age of the world or the number of years elapsed since the birth of Jesus Christ. By his calculations, the time spanned from the first generation of Indians (Vari Vira Cocha Runa) through the end of the reign of the Incas, who ruled for fifteen hundred years according to his calculus, was six thousand years. The time spanned from the birth of Jesus Christ, which Guaman Poma represented as having occurred during the reign of the second Inca, Sinche Roca, until the present was more than sixteen hundred years. He thus indirectly referenced the years 1612 and 1613 in the course of his writing (Guaman Poma 1980:13, 49, 55, 58, 87, 91, 437).

Cosmology aside, Guaman Poma used dates to document events he witnessed or, in one case, an interview conducted, in the style of the inspection tour official preparing his documentary report (1980:502, 519, 592, 595, 638, 687, 693, 704, 933, 944, 1114; see below, "Writing and Religion: The Visita Report"). The earliest date Guaman Poma mentions 
(apart from the apocryphal reference to 1587 ) is 1600 , which he acknowledges as the year he began his peregrinations. The latest year is 1615, and it marks the (18 December) 1615 conclusion of Don Juan de Mendoza y Luna's governance of Peru as its tenth viceroy (Guaman Poma 1980:474, 886). From these collected references we can surmise that the Nueva corónica y buen gobierno was written after 1600 , and that this, its final version, potentially was drafted in the period from 1608 to 1615.

Regarding the facsimile reproduction of the manuscript, Fraser (1996:283) has remarked on the loss of the sense of Guaman Poma's artistry due not only to the accumulated generations of facsimile reproduction but also to the possible retracing of the manuscript onto an overlay prior to the publication of the 1936 Paris facsimile. I too had speculated about the possiblilty of a universal retracing of the manuscript (Adorno 1979-80:19-20,28n23). Based on my 1977 investigation of the autograph document, I made note of varied amounts of noticeable reetching in the facsimile's pages $190-425$ and 1094-1128 where the autograph manuscript exhibits lacunae or its text is obscured by oncetransparent paper strips applied in the 1920s to protect damaged pages (Adorno 1979-80:19-20,28). Comparison of the autograph manuscript with the Paris facsimile also revealed that where the most noticeable retracing did occur, as in the Nueva corónica chapters on ritual feasts and "idols and huacas" (see esp. Guaman Poma 1936:236-272), the results produced were so crude that their differences from the original drawings are immediately recognizable. Yet the retouching is considerable and significant, as Fraser also has observed (1996:283-285), and her remarks led me to consult afresh the Royal Library's 1930-31 correspondence between Dr. Paul Rivet, Director of l'Institut d'Ethnologie in Paris, and Dr. Paludan, Director of the Royal Library, during the early stages of the facsimile's preparation.

According to this exchange of letters, the Royal Library produced white-on-black photographic reproductions of the 1200 pages of the manuscript, which were sent from Copenhagen on 28 May 1930 and received in Paris on 7 June 1930. Subsequent correspondence from Paludan to Rivet confirms that the reproductions were simple, direct photographic reproductions of the original (Konelige Biblioteks arkiv, Journalslager no. 4271). Yet the grievous problems of ink bleeding 
through the pages, muddling images and obscuring lines of text, as well as the occasional tear, prompted Rivet to seek help from the Royal Library. Various solutions were suggested and rejected until the Director of the Royal Library acceded to Rivet's request, and the correction of the facsimile page proofs was carried out at the Royal Library itself(Konelige Biblioteks arkiv, Journalsager, no. 2854; Guaman Poma 1936:v). Here, then, is a needed correction to my previous assumption that the proofs were corrected in Paris without access to the original (Adorno 1979$80: 20$ ). As to whether the entire manuscript has been retraced, this remains an open question. If there is an answer, it is likely to be found in the Paris documentation regarding procedures undertaken after the page proofs corrected in Copenhagen were received in Paris, sometime after late 1931 .

\section{Recent Advances in the Study of Guaman Poma's Visual and Verbal Art}

As an object in its own right, the autograph manuscript in Copenhagen is a work of considerable delicacy and beauty, and the issues of artistic composition and aesthetic traits that it raises have been examined by Valerie Fraser (1996). She opens a new area of study by looking at Guaman Poma's calligraphy, which she qualifies as the unifying feature of the entire work. She has brilliantly described Guaman Poma's handling of the pen to set forth the quality and versatility of his artistry (ibid.:283-285). Drawing attention to Guaman Poma's mastery of techniques of drawing and calligraphy as well as his familiarity with a wide range of European iconographic and compositional types, Fraser sets forth the hallmarks of his extraordinary visual acuity (ibid.:274, 285). Her examination of Guaman Poma's introduction of imagery into his written texts complements earlier studies of the introduction of verbal information into his drawings in which, as I note in chapter 4, "language floats free from the constraints placed on it in verbal narration" (see also Cummins 1992; López Baralt 1988, 1992, 1993). Fraser (1996:285) cites Guaman Poma's success in "blurring the distinctions between text and image, integrating imagery into the text by means of inventive uses of lettering, incorporating text into images, and blending one page into the next."

The language of the Nueva corónica y buen gobierno has been closely 
studied in recent years, and scholars agree that Guaman Poma's writing reveals that he spoke more than one dialect (Husson 1985; Szeminski 1993:10-11), perhaps at least three varieties of Quechua and two or three of Aru, related to Aymara (Szeminski 1993:14). Jan Szeminski(1993:13) has identified Guaman Poma's use of three Quechua dialects as follows: one that Guaman Poma identified with the Inca, another that he cued as Quechua as spoken by Spaniards, and a third "middle language" based on Quechua syntax and Spanish morphemes. His knowledge of Aymara seems to be that found in the province of the Aymaraes, located in the present-day Department of Apurimac, Peru, rather than the principal Aymara-speaking area of Collasuyo, about which Guaman Poma's clichéd references suggest only indirect knowledge (Albó and Layme 1993:16).

Guaman Poma renders in Quechua lyric traditions that are identified with pre-Hispanic Cuzco, and, in Aymara, those emanating from the province of Aymaraes (Husson 1985, 1995:61-65; Albó and Layme 1993:16). The important studies of Jean-Philippe Husson $(1985,1995)$ on Quechua lyrical and oral traditions in the Nueva corónica y buen gobierno reveal a significant dimension of Guaman Poma's verbal art, and they are complemented by Urioste's (1980:xxiii-xxviii; 1987:1xvlxxvii) studies of Guaman Poma's styles of speech in Quechua and Mannheim's (1986) examination of Guaman Poma's Quechua lyric.

Guaman Poma's Spanish likewise presents a complicated picture. If earlier commentators of the 1940 s-50s emphasized his errors of grammar, today's scholars focus on his linguistic control. The influence of Quechua in the phonology, grammar, and syntax of Guaman Poma's written Spanish has been carefully analyzed (Urioste 1980:xxviii-xxi; Szeminski 1993:9; Cárdenas Bunsen 1998:101-138). The language of his prose is asserted to be close to the standard oral norms for Castilian in the late sixteenth and early seventeenth centuries (Cárdenas Bunsen 1998:143). Despite its formal problems, Guaman Poma's Spanish prose is highly expressive and rhetorically effective. Cárdenas Bunsen (ibid.) characterizes the prose of the Nueva corónica y buen gobierno as remarkable in its mastery and manipulation of the rhetorical resources of written language, revealing Guaman Poma's finely honed linguistic consciousness and his refined capacity for representing distinct registers and types of speakers. The demonstration of this linguistic and rhetorical 
virtuosity can be found in chapter 3, where I examine Guaman Poma's recreation and uses of the Christian sermon.

The links that have been drawn between Guaman Poma's work and various Andean and European intellectual and artistic traditions are manifold. The question of his cosmology and concept of time has invited frequent reexamination (Imbelloni 1944; Ossio 1970, 1973, 1977; Duviols 1980; Szeminski 1983; Fleming 1994; Barnes 1995; Pease 1995; Plas 1996). The renewal of this discussion highlights the complexity of the issues at stake and reaffirms the importance of conceiving Guaman Poma's elaborations as part of larger cultural interactions and/or alternate traditions (Adorno 1992:347; Barnes 1994:236; Fraser 1996:274). The current and independently discovered identification of Guaman Poma's specific source for his paradigm of five or six ages as Jerónimo de Chaves's Chronografia o Repertorio de los tiempos (Seville, 1548) (Fleming 1994; Barnes 1995; Plas 1996) suggests both Guaman Poma's choice of a European model that resonates with his own Andean ideas of time and change as well as his creative manipulation of written and traditional oral sources. Salomon (1999:42-59) offers a brief, brilliant assessment of Guaman Poma's complex historical and cosmological perspective and situates the discussion in the broader context of current ethnohistorical efforts to "transcend habitual dichotomies like 'myth' and 'history,' and to imagine how human continuity appeared when memories were grouped under less familiar premises."

Of the relationships drawn between the Nueva corónica y buen gobierno and Andean and European tradition, none is more direct or pervasive than the visual evidence supporting Guaman Poma's artistic relationship to Fray Martín de Murúa; even Guaman Poma's narrative conceptualization of his history of the Incas follows the outline set forth in Murúa's 1590 Historia del Perú (Cummins 1992, 1993, 1997; see also Ballesteros Gaibrois 1978-79, 1981; Mendizábal Losack 1961, 1963). Additional recent evidence of this relationship is Juan Ossio's (1998, 1999) discovery of the models for Guaman Poma's (1980:87-143) visual depictions and verbal descriptions of the costumes and colors of the Incas' and Coyas' dress in his history of the Incas. The models are the corresponding watercolor drawings in the recently recovered Murúa manuscript of 1590 (the so-called Loyola manuscript), which thus reveals a long-held secret (on which I comment in chapter 2) about one 
of the crucial sources of Guaman Poma's visual information. Along other lines, Van de Guchte (1992) shows Guaman Poma's use of iconographic types derived from earlier, northern European compositions disseminated to Spain and Spanish America through generations of reproduction in woodcut engravings; López Baralt (1988, 1993), Cummins (1992), and Gisbert (1992) have also contributed to our understanding of Guaman Poma's use of European visual sources.

New work by R. Tom Zuidema (1991) offers a key to understanding, within the Andean tradition, the relationship between textile designs, patterns of Inca administration, and imperial social distinctions. Yet even as Zuidema's work reveals the ritual use of Inca dress, particularly the woven abstract designs (tukapu) adorning Inca tunics, he (1994:38) also emphasizes that Guaman Poma takes his pictorial contexts from European models and thus modifies the mythical, ritual, and political intent of his subject matter as well as the historical events in which his subjects play a role.

On Andean textile design per se, Cummins (1997) shows that Guaman Poma has little to say, and he emphasizes that Guaman Poma refrains from explicating the encoded meanings of Andean objects, such as the khipukamayuq's abacus that appears in his drawings, and that he likewise refuses to elucidate the independent mnemonic function of objects for recalling Inca history, such as Albornoz himself had examined and detailed. Cummins (ibid.:238) has argued, in fact, that "Guaman Poma's hermetic and hermeneutic world of text and illustration shields from us some fundamental aspects of Andean and colonial Andean imagery."

Gary Urton's (1997) recent study of the Quechua ontology of numbers and philosophy of arithmetic adds another dimension to Guaman Poma's representation of traditional Inca tukapus. He (ibid.:208) concludes that if the use and meaning of tukapus as adduced by Cummins and Zuidema are correct, then it is possible to argue that Guaman Poma "recognized in the two systems of signs similar instruments of representation whereby two different states, the Inkaic and the Spanish, used complex symbols, which were little understood by the people at large, to signify systems of ranking (that is, ordinal sequences) and organization whereby control over political, social, and economic affairs and resources was established and maintained." Furthermore, Urton (ibid.) continues, in Guaman Poma's view of the matter, the "instruments of the political arithmetic of 
the Spaniards - that is, Hindu-Arabic numerals - were on a par ... with the God of Christianity as elements that could not be compromised, or translated, into a supposed Andean equivalent if his argument to the king of Spain for the integrity and high level of achievement of Andean civilization was to prove successful." Overall, the outstanding work done in recent years by a number of distinguished scholars serves as testimony to the conceptual power and complexity of the Nueva corónica y buen gobierno and the ongoing pursuit of its still untapped riches.

\section{Guaman Poma in the 1590s}

We turn now to Guaman Poma's biography and the external documentation that brings into sharp focus one of the most significant decades of his life. As we will see, the relationship of the chronicle to documents and drawings external to it elaborates a literary, artistic, and documentary "network" whose elements mutually support and verify one another. This synchronic articulation gives strong evidence of the internal coherence of the Nueva corónica y buen gobierno and its consistency with the documentary base that provides its necessary context and verifies its essential content.

\section{The Expediente Prado Tello}

The Expediente Prado Tello tells the story of the litigation between Guaman Poma and the Chachapoyas of Huamanga, and it allows us to situate the genesis of the Nueva corónica y buen gobierno as subsequent to it. Anticipated by the world of Andean scholarship since the 1950s when the Monsignor Elías Prado Tello published its relevant fragments, the full publication in 1991 of the dossier that had been in his family's possession since the end of the nineteenth century provides significant information about the activities of the Andean chronicler. Guaman Poma's work can be understood first and best by taking into account his earlier efforts to establish, before the colonial authorities, his ethnic and legal identity in relation to the lands he claimed to be his since time immemorial.

The Expediente Prado Tello is a seventeenth-century copy of the original dossier, dating from 1646 or shortly afterward (Macera 1991:27). Containing accounts of legal actions regarding the area of the valley of 
Chupas just outside the new colonial city of Huamanga (today's Ayacucho) in south central Peru, the Expediente offers data for the reconstruction of the history of the peoples of the Chupas valley and other matters pertinent to the rural area of Huamanga in the first decades of the colonial era (Prado Tello and Prado Prado 1991:14). The period covered extends from the second half of the sixteenth century to about 1640 . The portion referring to Guaman Poma consists of claims made by the heirs of Don Domingo Guaman Malqui de Ayala and Don Juan Tingo to the lands of Chupas, which, according to Guaman Poma, was the original name of the valley of Huamanga. The disputed area included the native settlements of Andas, Palca, Pacainoc, Rantavilca, Querapampa, and Chiara Urco. The lands of Chupas were vulnerable because of their proximity to the growing city of Huamanga with its wealthy resident encomenderos (holders of grants of Indian tribute and labor) and miners from Huancavelica and its abundant, increasing population of mestizos, mulattoes, and vagabond Indians (Macera 1991:29).

In general, we find that Guaman Poma's assertions reflect the attitudes and actions of the Andean provincial elite from the mid-sixteenth century onward. On the whole, the native elite responded eagerly to the chance to seek offices and privileges in the colonial system. From the $1550 \mathrm{~s}$ onward, native lords had served as subordinates to Spanish colonial administrators (Guaman Poma's documented experience is an example), and they continued to compete for positions in the Spanish colonial bireaucracy after the reorganization of native society under Toledo (Spalding 1984:219-223). In the 1570s, Toledo revamped the ethnic power structure, institutionalizing state control over the succession of kurakakuna (Andean ethnic lords) and converting them into agents of the state for overseeing the directed activities of the local community (Larson 1988:71-72). Like many others, Guaman Poma participated in the transactions of official colonial society, yet, as we shall see, his colonial affiliations were no match for those of the Chachapoyas against whom he competed for the disputed properties.

There is general agreement that Guaman Poma was descended from mitmaqkuna (members of an ethnic community sent with special privileges by the Inca to settle a newly conquered area), who originated in Huánuco and eventually settled in Huamanga; the timing of this migration has been estimated to have occurred in the fifteenth century (Macera 
1991:28). Insofar as Guaman Poma's mitmaq heritage affected the way he defended his lands and shaped his later literary work, it is important to clarify the Inca concept and its evolution into colonial times. In the Inca state, the mitmaqkuna served the purposes of settling newly conquered areas (Guaman Poma Huánuco forebears' case), providing military garrisons along the vulnerable eastern borders of the kingdom, or populating potentially productive but uncultivated and vacant lands (Cieza de León [1553] 1985:63-66 [chap. 22]). While they submitted to local administrative rule in their new place of residence, they maintained the dress and symbols of their ethnic homeland. Their duties were to teach the superior ways of Inca culture (religion and language) to the local population (Cobo [1653] 1979:190).

With the arrival of the Europeans, the status and prestige of mitmaqkuna were lost as the concept took on new meanings. In the 1570s, Toledo fixed permanent residences for these mitimaes, as they were called in Spanish (Wightman 1990:86). They were assigned to the places where they were residing at the time, thus separating them and their descendants from the local ayllu, which was the basic kin unit of native Andean society that held title to land, organized cooperative labor teams, and performed other collective functions (Larson 1988:333; Wightman 1990:87).

Relevant to our discussion is Toledo's division of the indigenous community into two clearly defined categories: originarios, native-born members of organized Indian settlements, and yanaconas, Indians detached from their ayllu affiliations and living in the service of Europeans (Wightman 1990:52-53). Forastero and yanacona were terms used to refer to "outsiders" or "migrants to the community from elsewhere," and former migrants retained the name forastero regardless of the length of their residence in new communities and degree of assimilation (ibid.:53). In the seventeenth century, colonial officials attempted to distinguish "forasteros revisitados, those "who live in their respective ayllus because their ancestors were born here and were integrated into these communities,' from the 'forasteros advenedizos and other recent arrivals who at present are found within the ayllus but leave at will" (ibid.:54). Removed from indigenous society, yanaconas constituted a heterogeneous and transitional social group designated by Toledo as yanaconas de españoles (those in personal service to private citizens) and yanaconas del Rey 
(those in service to the king's authorities) (ibid.:17-18).

Guaman Poma's case illuminates the situation of Indians designated as forasteros under the Spanish colonial system, and his story illustrates the principle elucidated by Ann Wightman (ibid.:135) to the effect that "land-tenure cases were among the most hotly contested within the colonial judicial system, and the rising value of land and the shrinking assets of indigenous communities provoked bitter disputes." "Migration," Wightman concludes, "complicated the debates over land inheritance and titles in ways which were reflected in the courts throughout the seventeenth century."

The Expediente Prado Tello and the Compulsa Ayacucho, which records the criminal sentence handed down against Guaman Poma in 1600 (Zorrilla 1977), are mutually illuminating in this regard, and both are reflected in the Nueva corónica y buen gobierno. Recalling but not describing the events of that year in the Nueva corónica, Guaman Poma lamented that "petitions end up as losses" and, in a play on words that he also used elsewhere to contrast Inca times with the colonial era, he described judicial advocates as thieves (procuradores as "proculadrones") (Guaman Poma 1980:309, 918).

The chronicle's elliptical account of the Compulsa's events confirms that the Felipe Guaman Poma of the chronicle and the one criminally charged and sentenced in the Compulsa Ayacucho are the same person (Guaman Poma 1980: 3:1155-1156; Guillén Guillén 1969). However, the Expediente lays to rest any notion that Guaman Poma might have used a fraudulent identity as charged in the Compulsa. Thanks to the Expediente, we can confirm that, contrary to the sentence pronounced against Guaman Poma in December 1600 in which he was branded a humble Indian by the name of "Lázaro," Guaman Poma belonged to the distinguished Guaman/Tingo clans and was recognized as such during the decade (1590s) of the litigation carried out in Lima and Huamanga.

In the Expediente (Prado Tello and Prado Prado 1991:338-339), Guaman Poma identifies himself as both a member of the local native elite (cacique principal) and as an appointee of the Spanish colonial government (gobernador de los indios y administrador de la provincia de los Lucanas). In the Nueva corónica $(1980: 823,1106)$ he uses a similar title, administrador, protetor, tiniente general de corregidor (adminis- 
trator, Indians' advocate, deputy of the administrator of the colonial district) and, through his corrections to the manuscript, elevates the hereditary title of cacique principal to that of capac ques prencipe, ("qhapaq, which means prince") (Pietschmann 1936:xiii; Adorno 1980: xli). In each case, he reflects the need to assert both traditional inherited status as well as a new colonial one. His inflation of the titles he used in passing from the Expediente to the chronicle correspond, as we shall see, to the development of his literary pursuit in the face of his personal judicial defeat. The Expediente Prado Tello allows us to trace Guaman Poma's transformation from local claimant and petitioner to someone who considerably enlarged his perspective without ever losing sight of his own interests (Adorno 1993).

\section{Guaman Poma in the Expediente Prado Tello}

The portion of the Expediente that refers to Guaman Poma and consists of the claims made by the heirs of Don Domingo Guaman Malqui de Ayala and Don Juan Tingo contains drawings of Guaman Malqui and Juan Tingo, as well as a map of the jurisdiction of Huamanga that includes Chupas and the hydraulic network formed by the Guatata, La Tenería, Yanayaco, and Viñaca rivers (Prado Tello and Prado Prado 1991:157, 163, 167-168). The Expediente's portrait of Don Domingo Guaman Malqui, obviously a copy of the original drawing that Guaman Poma must have submitted to accompany his suit, is identical to his portrait of his grandfather Guaman Chaua in the Nueva corónica, with one small variant: Guaman Chaua's hammered metal wrist cuff is turned away from the viewer, and the calves of his legs are covered by fringed leggings (Prado Tello and Prado Prado 1991:326; Guaman Poma 1980:167).

Monica Barnes (1999) has identified the Expediente's map as the first known cartographic representation of any area that falls within today's Department of Ayacucho. Its drawings of roads, churches, and the city of Huamanga bring together all the iconographic elements that are repeated in the Nueva corónica y buen gobierno's chapter on the "cities and villas of the kingdom" (Prado Tello and Prado Prado 1991:167-168; Guaman Poma 1980:1057; see also 1009, 1021, 1023, 1035, 1041, 1051, 1055).

The prose of Guaman Poma's petitions in the Expediente likewise finds its full development in the Nueva corónica y buen gobierno. With respect to orthography, grammar, and lexicon, the Nueva corónica y buen 
gobierno and the Expediente are identical. Grammatically (see Urioste 1980), both texts are characterized by the lack of correspondence in number and gender between noun and/or verb phrases ("an armado casas .. . no las quiere rremediar") as well as by the use of nominal phrases characterized by ñisqa ("los dichos españoles," "las dichas mis tierras"). The shared lexicon of both texts, the use of rhetorical techniques such as the polysyndeton, and the typical lament that serves as the signature of both prose texts - "no las quiere rremediar ni ay rremedio"-reveal their common author. In the chronicle as in the Expediente, Guaman Poma insists that his land rights be recognized against the counterclaims of his litigating enemies, the Chachapoyas, and he remarks that his family's titles to land in the area have been recognized "since the time of the Inca" (Prado Tello and Prado Prado 1991:331, 332, 336, 345, 347, 348, 360, 365, 366; Guaman Poma 1980:918).

Overall, the Expediente reveals that by the middle of the decade of 1590 Felipe Guaman Poma had already conceptualized and realized some of the graphic compositions and forms of argumentation that he would employ later over the entire extension of his major work. By all these formal and thematic means the author of the Nueva corónica y buen gobierno is linked definitively with the plaintiff in the Expediente Prado Tello: the same hand, the same voice, the same mind.

With respect to his own claims to the area of Chupas, Guaman Poma accuses his enemies of being advenedizos, but he never acknowledges that he and his kinsmen are themselves descendants of mitmaqkuna. The situation is further complicated by the fact that both Guaman Poma's ancestors and those of the Chachapoyas came from the Inca tradition of mitmaqkuna that suffered modification in Spanish colonial times. Since the formerly prestigious title now carried unwanted meanings prejudicial to the pursuit of land claims, the identification as immigrant was used for accusation rather than self-representation. Guaman Poma's loss of his claims can be attributed directly to his enemies' success in persuading the authorities that he was a humble outsider rather than a member of a distinguished local clan.

In seeking to assert dominion over the Chupas territory on behalf of himself and the heirs of Don Juan Tingo, Guaman Poma charged many groups and individuals with having run over, or having attempted to take over, the territories that he claimed his ancestors had held since the time 
of Tupac Inca Yupanqui (Prado Tello and Prado Prado 1991:347, 360361 ). In the litigation (as later in the chronicle), he asserted that his forefathers had helped found the colonial city of Huamanga. Subsequently, he said, he himself had maintained the church and chapel of San Felipe in the middle of the district of Chupas, so that "our Indians, caretakers of flock and field, can go to mass." He also claimed to have had other caciques principales as well as yanaconas in his service (ibid.:345, 360 ). In the angry language of these petitions, he demanded that the interloper Indians be returned to their own districts and parishes to perform the required personal services, that their encomenderos have them gathered up and returned to their communities, and that they pay tribute and work in His Majesty's mines as required (ibid.:362, 364).

In the sixth of the petitions he filed, probably during the year 1597 , Guaman Poma spelled out his most complete list of claims (ibid.:365366). First, he insisted, "before the arrival of the Spaniards, and since the beginning of time," his ancestors had been natives to the area of Huamanga. Second, during the reign of the Incas, Tupac Inca Yupanqui reaffirmed the grant. Third, Guaman Poma claimed that soon after the arrival of the Europeans his forebears received a royal decree from the Spanish monarch allowing them to live on their "inherited possessions and lands and estates as granted by the Inca" (ibid.:365). While Guaman Poma echoes his claims of biblical- and Inca-era settlement in the Nueva corónića y buen gobierno (1980:918), his mention of the king's decree may be an allusion to the 1557 visita of Huamanga by Damián de la Bandera (Jiménez de la Espada [1881-97] 1965, 1:176-180). Guaman Poma $(1980: 410-411,454)$ would later discuss this visita and draw a portrait of Bandera in the Nueva corónica y buen gobierno, thus underscoring his apparent early acquaintance with systematic efforts at censustaking as well as the acknowledgment of his family's establishment in the area.

Continuing his appeal in the Expediente, Guaman Poma next cites the general inspection tour of the viceroy Toledo, "who commanded by royal order of His Majesty and the ordinances of these kingdoms that we be allowed to live peacefully according to the title to our lands and landmarks and other possessions that Tupac Inca Yupanqui gave us as naturales [original inhabitants]" (Prado Tello and Prado Prado 1991: 365). Finally, Guaman Poma makes claims to the lands of Chupas on the 
basis of a recent general inspection tour and confirmation of land titles, as well as a royal decree that demanded the return of his usurped lands and freedom from harassment and suits (ibid.: 365-366). He probably refers to the first composición de tierras (land-title confirmation hearings), granting titles to native residents that occurred in Huamanga in 1594 and in which Guaman Poma had participated as an interpreter (Stern 1978:226228; Pereyra Chávez 1997:267-268). The "royal decree" no doubt corresponds to the dispositions issued and recorded in the Expediente in July and August 1595 (Prado Tello and Prado Prado 1991:359) on the basis of a grant to the lands given by the judge inspector Gabriel Solano de Figueroa. Guaman Poma (1980:918) later summarizes this entire list of claims, though somewhat elliptically, in the Nueva corónica y buen gobierno when he refers to the defense of lands that had been his by right "since God created the earth and since the time of the Incas, and His Majesty and his Audiencia knowing the truth which was recognized, confirmed, and reconfirmed by the lord viceroys, and the said lands and valley of Santa Catalina de Chupas were inspected, where the battle of Don Diego de Almagro the younger against the crown had taken place."

\section{Guaman Poma versus Don Domingo Jauli and the Chachapoyas}

The Chachapoyas were an ethnic and possibly a linguistic group originating in the eastern highlands and western Amazonian slopes of today's northern Peru. They had been assigned by the Inca state to the Quito area where they were living at the time of the Spanish invasion (Salomon 1986:158-159). Frank Salomon (ibid.:160) characterizes the Chacha groups as "small homogeneous enclaves forming a far-flung net of small mitmaj operations," that were found "at the outskirts of former aboriginal sites which had been converted into Inca centers," possibly with "responsibility for controlling the interaction of aborigines with the privileged population of the new citadels." The Chachapoyas had not been conquered until the reign of the Inca Huayna Capac (Hemming 1970:247-248), but when the Spanish took over Peru the Chachapoyas quickly assimilated themselves into the royal forces as "modern soldiers," according to John Murra (in Guaman Poma 1980: 3:1138), continuing the role they had played in late Inca times.

In mid-1538, the powerful Chachapoyas joined the forces of Alonso de Alvarado under the royal banner and subsequently served Alvarado as 
auxiliaries in the royal army that defeated the rebellion of Diego de Almagro the younger in the battle of Chupas in 1542. (In the Nueva corónica y buen gobierno Guaman Poma [1980:415, 750, 1058] repeatedly asserts that his father, Don Martín de Ayala, and clansman, the Cavinga Inca Don Juan Tingo, had served the crown in the same signal effort.) After the royal victory, the governor Cristóbal de Vaca de Castro settled the Chachapoyas nearby at Santa Lucia de Chiara in the valley of Chupas and exempted them in perpetuity from tribute payment in recognition of their loyalty and military prowess (Hemming 1970:247$248,604)$. In the Compulsa Ayacucho they are identified as being in service to the "justice officials of this city [Huamanga] and the royal crown" (Zorrilla 1977:59).

According to the Compulsa Ayacucho, the struggle over the lands of Chiara, located some two leagues from the city of Huamanga, began in 1586 (Zorrilla 1977:57). In Lima on 19 November 1586 the viceroy Fernando de Torres y Portugal granted the presumably vacant lands of Agua Puquio and Chiara to Don Baltazar Solsol and the Chachapoyas. Reasons given were their status as mitmaqkuna, as well as their ongoing service to the crown in law enforcement in Huamanga; granting them land on which to settle and sow was thus presumably based on need and merit (ibid.:51). The lands are described in the decree as being vacant "for more than fifty years, since they had been the lands of the Inca and the sun" (ibid.). On such a basis, lands were typically considered to be unencumbered by any legal claims to ownership (Wightman 1990:78-79).

After the lands of Chiara were surveyed on 8 February 1587, and on the basis of their title of possession, it seems that the Chachapoyas were soon to be established in Chiara. However, the Expediente Prado Tello reveals that just two months later (in April 1587), a member of the Tingo/ Guaman families claimed and received the same lands from the same corregidor's deputy, Juan Pérez de Gamboa. Doña Inés Coca, the legitimate daughter of the deceased Don Juan Tingo, appeared before Pérez de Gamboa and claimed fields and forests, including those of Chiara. On 24 April 1587, Pérez de Gamboa upheld her claim and the judge inspector Gabriel Solano de Figueroa ordered that it be honored (Prado Tello and Prado Prado 1991:350-351). The next legal action recorded in the Expediente and the Compulsa occurs seven years later.

The Compulsa Ayacucho (Zorrilla 1977:57-58) informs us that in 
September 1594, the rights of the Chachapoyas to the lands of Chiara, as granted in February 1587, were confirmed by the judicial officer Vasco Juárez de Ávila on behalf of the judge inspector Gabriel Solano de Figueroa. Again, just a few months later according to the Expediente, the Guaman/Tingo families' claim to Chiara of April 1587 was also upheld. Stern (1978:226) has mentioned that Guaman Poma had obtained a royally approved title (ejecutoria real) in his favor, and the Expediente Prado Tello (1991:351-352) gives the particulars: On 16 November 1594 the chief constable of the city of Huamanga, Lorenzo Chungui, notified the Guaman/Tingo heirs in Rantavilca that they should "have and recognize as theirs from this day forward and as in the past" their rights to the hills of Chiara and Rantavilca and all the fields and alder-tree groves found from Andas to the Camino Real leading to Cuzco. Curiously, one of the witnesses to this action was Diego Yanga Tuiro, principal of Acocro, who would later claim these very lands from the Guaman/Tingo heirs.

When on the same 16 November 1594 Chungui notified the Chachapoyas of Chiara of this disposition favoring the Guaman/Tingo heirs, the Chachapoyas claimed that they had received the rights to those fields and forests many years earlier from the deceased Don Juan Tingo himself, and that his daughter, the current plaintiff, Doña Inés Coca, had allowed them to cultivate the land (Prado Tello and Prado Prado 1991:351). In fact, they said, the now defunct Tingo had made this grant to them at the time the city of Huamanga was founded (1539) and that at that time Tingo had also granted them substantial amounts of open and forested land (ibid.). The Compulsa Ayacucho (Zorrilla 1977:52), however, states that the "Chachapoyas del rey" had been granted the Chiara lands in $1586-87$, that is, five decades later than the date they now claimed to be the source of the grant. The apparent contradiction reveals the negotiations and renegotiations into which migrant claimants had to enter in order to make or hold claim to their lands.

Notwithstanding the Chachapoya protests, the renewed Tingo/Guaman claims were upheld. On 15 July 1595 the municipal magistrate of Huamanga, Antonio de Chávez, authorized Juan Lucas de Valencia to go to the indicated places and execute the order of possession on behalf of the Tingo/Guaman heirs (Prado Tello and Prado Prado 1991:358). Thus, on 20 July 1595 Valencia installed "Martín de Ayala and Isabel de Ayala 
and Alonso Guamani" in the lands of Andas and Palca and Pacainoc. Guamani and the Ayalas accepted possession and certification was given thereof. On 9 August 1595 Valencia installed them in the lands of Rantavilca, Quera Pampa, Poma Guarmi, and "all the other places contained in the title and decree authorized by Juan Pérez de Gamboa and Gabriel Solano de Figueroa," including Chiara Urco (ibid.:359). Again we find that witnesses on one occasion become plaintiffs on another; witnesses to this proceeding were none other than "Don Juan Yupanqui and Domingo Sauli [sic] and Juan Pantoxa, Chachapoyas" (ibid.:360). On 20 October 1595 the Guaman/Tingo titles to these lands were confirmed in Lima by the Royal Audiencia, the highest civil and criminal court of the viceroyalty (ibid.).

In an undated petition that would fall between the middle of 1595 and the middle of 1597 (assuming that the relationship of petition to disposition in the Expediente is chronological and consequential), Guaman Poma again appeared among the plaintiffs. He identified himself, as in an earlier petition, as Don Felipe Guaman Poma, "cacique principal and administrator of the province of the Soras and Lucanas, Andamarcas and Circamarca" (ibid.:338, 360). He and his coplaintiff, Doña Juana Chuquitinta, identified themselves as the "eldest and legitimate children of the deceased Don Juan Tingo and Don Domingo Guaman Malqui, cacique principal y gobernador," and they filed a long complaint about their lands being overrun by intruders (ibid.:360-369).

They asserted that runaway Indians from many places had overrun Chiara Urco and they cited, among others, "Domingo Sauli [sic] and his brothers Juan Pantoya and Juan Sota" for stealing livestock, taking over their lands, and bearing arms and assaulting people on the highways (ibid.:362-363). And, "besides all this," Guaman Poma and Doña Juana asserted, "they have usurped the entire site of Chiara Urco and have sown some twenty topos [approximately thirty leagues] of our land" (ibid.:364). Guaman Poma and Doña Juana Chuquitinta defended these claims on the basis of the royal confirmation they had received (ibid.:365-366). We can deduce that this referred to the transactions, documented above, of July and October 1595.

\section{The Conclusion of the Land-Title Litigation}

More dramatic than this petition was the request, filed in Huamanga by Guaman Poma and Doña Juana on 13 June 1597, to have Domingo 
Jauli and Cristóbal Yangaiachi arrested (ibid.:369). On 16 July 1597 the current chief constable of Huamanga, Fabián de Barrios, went to Chiara Urco and notified "Domingo Sauli" that the lands belonged to the Guamanes and that henceforth he should not perturb "the said Alonso Guamani and his wife and Martín de Ayala," either in their fields or wooded areas, under pain of punishment. Jauli acknowledged receipt of the notice (ibid.:370). Although this document executed the action taken only a month earlier, the names of Guaman Poma and Doña Juana are replaced by those of other family members, Martín de Ayala and Inés Coca.

This Martín de Ayala is obviously not the father of Guaman Poma referred to earlier in the Expediente (ibid.:326), but rather a brother or other relative. This is more likely to be another brother of Guaman Poma, mentioned in the Nueva corónica y buen gobierno $(1980: 76,754)$, rather than his elder half-brother, the mestizo hermit priest Father Martín de Ayala. (Guaman Poma describes the latter as being deceased at the age of forty, apparently sometime in the late 1570 s or early 1580 s, after having accompanied Martín Hurtado de Arbieto's 1572 expedition into the montaña in pursuit of the Inca prince Tupac Amaru [Guaman Poma 1980:14-21, 395, 463, 612-613, 747, 1040]).

Subsequently, in a petition probably written in July or August 1597 (it precedes a disposition dated 19 August 1597), Guaman Poma emphasized how costly the effort to defend his rights had been, and he accused Domingo Jauli's mistress and her mother of being publicly acknowledged as witches ("hechiceros públicos [sic]"), who had been exiled from the hospital of Huamanga and who had poisoned two heirs of Don Juan Tingo (Prado Tello and Prado Prado 1991:343). Through threats of harm and promises of cures, Guaman Poma declared, Domingo Jauli continually intimidated the Indians of the area in order to coerce them into silence (ibid.:343-344).

On this occasion Guaman Poma claimed that the Chachapoyas had arrived in Chiara only about six years earlier; subsequently he names the year they received their royal provision as 1592 (ibid.:335, 342). He named Domingo Jauli, Juan Sota, and Juan Pantoja as "cobblers, Chachapoyas" and recent immigrants (advenedizos), who for some six years had held a small portion of land in the area of Chiara Urco. Guaman Poma insisted that the Chachapoyas had not been settled there in Inca times, that they had been among the newcomers who had come from 
Chachapoyas and Quito, and that therefore they had no right to hold the alder-tree forests and woodlands in the area (ibid.:335). In the same petition, Guaman Poma charged that both Spaniards and Chachapoyas had invaded his lands, moved boundary markers, and raised houses and chapels - even though there was already a church in one of his settlements (ibid.:338).

In another petition, also probably from 1597 since it precedes a disposition issued on 26 April 1597, Guaman Poma specified that Jauli, Pantoja, and Sota and other "runaway Indians" (indios cimarrones) were granted a royal provision to ten topos of land in Chiara in the year 1592, and that at that time they had testified falsely that there existed no lawful heirs to the land. They benefited, he insisted, from the cooperation of the corregidor (administrator of a colonial district) and the Indians' public defender (protector de indios), whom the Chachapoyas had bribed with money and "shoes and boots that they had cobbled" (ibid.:342-343).

Guaman Poma and Doña Juana Chuquitinta subsequently had another petition filed on their behalf in Lima by their legal representative, Antonio de Neira, charging that the Spaniards disobeyed orders to stay off their property and continued to commit the same and greater offenses as before (ibid.:328). A ruling was then made in favor of the Guaman/Tingo families in Lima on 5 September 1597, a certified copy (traslado) of which was made for filing in Lima on 11 September 1597. Guaman Poma now carried the original 5 September 1597 disposition with him back to Huamanga (ibid.:329).

This action marks the accelerating chain of events that will bring Guaman Poma's legal struggles to an unhappy close. On 14 September in a year for which the date cannot be read but was probably 1597, Captain Esteban de Vega, legal representative of the Indians (protector de naturales), requested in Huamanga on behalf of Don Juan Tingo's wife and daughter, Doña María Bohatinta and Doña Inés Coca, and "Martín de Ayala, yanacona [servant] of the hospital of Huamanga," that the Chachapoyas and other "runaway Indians" be summoned before the judge inspector (Gabriel Solano de Figueroa) in Huamanga so that "the truth be determined and the grants which they have gained through sinister means be revoked" (ibid.:373-374). Vega (ibid.:373) referred specifically to "Diego Tirasina, Diego Yanjatuiro, and other Chachapoya Indians-Domingo Zapata [Zapato in the subsequent reference in the 
document] and Juan Pantoya and Juan Sota and the rest of the runaway Indians from different areas-who neither pay tribute nor perform any service, and who have taken over their [Guaman/Tingo] lands and forests and with false testimony have gained a royal decree from the Audiencia and the crown." The complaint about Jauli's ("Zapato") exemption from tribute payment may derive from recognition of the latter's vocation as cobbler (!) as well as from the general exemption granted to the Chachapoyas because of their role in law enforcement.

In his response to this plea, the inspector judge commanded the constable to summon the named parties (ibid.:374). ("Domingo Zapato" is evidently Domingo Jauli, the Chachapoya "cobbler," who is here as elsewhere associated with Juan Pantoja and Juan Sota. ) As noted earlier, Yanjatuiro, formerly a witness in the November 1594 confirmation of the Guaman/Tingo heirs' claims to Chiara and Rantavilca, now appears as their legal adversary.

From the Expediente (1991:332), we can surmise that this summons resulted in an adjudication that granted the contested lands in the valley of Chupas to the Guaman/Tingo clans, because a later request from Guaman Poma and Doña Inés Coca asked that the record of the survey and their title, dated 7 August 1598, be filed in the Royal Audiencia's official records. Still, it was difficult for Guaman Poma and his family to control the use of these lands. Two months later, on 27 October 1598, Guaman Poma wrote to the abbess of the convent of Santa Clara, complaining that many Indian intruders took inordinate amounts of firewood from his property, all in the name of supplying the convent (ibid.:374-375). The abbess Doña Leonor de Jesús responded that his charges were ridiculous ("cosa de risa") (ibid.:375).

Finally, on 6 March 1599, Guaman Poma was again at the Royal Audiencia in Lima, asking that documents he brought upholding his claims to the lands of Chiara be certified and recorded. After comparing them to other original documents and official copies, the royal notary Juan de Herrera verified the authenticity of those that Guaman Poma had brought and now provided certification for those that Guaman Poma would carry away (ibid.).

Our story of Guaman Poma's struggle to hold onto his lands would end triumphantly here, were it not for the Compulsa Ayacucho. The Compulsa allows us to interpret this last action of Guaman Poma, recorded in the 
Expediente Prado Tello, as a prelude to his return to Huamanga where, armed with official documentation upholding his land claims to Chupas, he would make his final pitched battle against the Chachapoyas. However, the summons that had been directed to the Chachapoyas by Guaman Poma's family and the Tingo heirs on 14 September, probably in 1597, suggests a weakness to those claims that Domingo Jauli would later exploit against Guaman Poma after the 1598-1599 dispositions in the latters' favor. As we have just seen, on that September 1597 occasion the Indian's legal advocate representing Guaman Poma, the captain Esteban de Vega, had made a reference to Martín de Ayala as a yanacona. The reference to one of Guaman Poma's family members as someone detached from the ethnic community casts a shadow over all of them as potential outsiders and recent immigrants to the Huamanga area. Although Guaman Poma earlier had accused the Chachapoyas of being recent immigrants (forasteros advenedizos), and indios cimarrones, the tide of events on this issue now would turn dramatically against him.

\section{Guaman Poma in 1600: The Sentence of Exile from Huamanga}

On 23 March 1600, in Huamanga and before the corregidor's deputy and justice official Pedro de Rivera, Domingo Jauli and Juan Sota criminally accused Guaman Poma of falsely presenting himself as a cacique who called himself Don Felipe; they claimed that he was instead a humble Indian named Lázaro. They charged that this "Don Felipe/ Lázaro" had secured a royal order to have the Chachapoyas' lands surveyed under false pretenses, and that he-the pretender "Don Felipe/ Lázaro"- had then failed to appear on the designated date at the Chiara site where the survey was to be carried out (Zorrilla 1977:59). Juan Sánchez, the municipal notary accompanying the survey team, affirmed that the alleged pretender "Don Felipe/Lázaro" had failed to present himself (ibid.:60).

Subsequent to this denunciation of Guaman Poma, no noteworthy legal event appears to have occurred in the subsequent months. The next action recorded in the Compulsa Ayacucho occurred on 18 December 1600 . On that date, the Chachapoyas' rights to Chiara were confirmed by the corregidor's deputy Gaspar Alonso Riero (ibid.:63). On that same 18 December 1600, a criminal sentence was imposed on Guaman Poma. As 
condemned in the verdict, his crimes consisted of being a "common Indian who, through deceit and trickery, called himself a cacique and was neither a cacique nor a principal, yet he subordinated Indians so that they respected him as such. He always behaved and sought offices with malicious intentions and deceits and was an Indian of evil inclinations and all the rest as should be evident" (ibid.). Thus Guaman Poma was sentenced to two hundred lashes to be administered publicly, and he was condemned to two years of exile from the city of Huamanga and its sixleague radius. If he violated the conditions of the sentence, his exile would be doubled to four years. The costs of the suit, furthermore, were to be borne by him (ibid.:63-64). On 19 December 1600 in Huamanga the sentence was proclaimed publicly (ibid.:63).

The punishments of banishment or death were not unusual in cases of false representation and false testimony. The thirteenth-century Siete partidas, still the fundamental, influential legal code in sixteenth-century Castile that was carried over to Indies legislation (Bonifaz 1955:246), confirms the principle. Committing false actions and misrepresenting the truth of matters constituted, according to the Siete partidas, "one of the greatest evils man can commit" (Alfonso X el Sabio [1263] 1587:f25v [Part. 7, tit. 7, law 1]). Knowingly alleging false laws and principles when engaging in a civil suit, giving false testimony, or knowingly denying the truth (all probable criminal charges against Guaman Poma) were crimes for which the suitable punishment was described as banishment and death (Alfonso X el Sabio [1263] 1587:f27a [Part. 7, tit. 7, law 6]; Bonifaz 1955:26). We do not know whether the corporal punishment was meted out, but Guaman Poma's banishment surely was.

Why had Domingo Jauli singled out Guaman Poma for criminal charges? No member of the Tingo family had been the target of attack. On the contrary, Domingo Jauli insisted that he and the "natives of Chupas," by which he meant the Chachapoyas, were friends and allies of the Cavinga Inca, that is, the Tingo clan. From this we infer that they charged only that "Don Felipe/Lázaro" had made legal claims under false pretenses (Zorrilla 1977:61). In the Expediente we learned about the persistence with which the Guaman/Tingo families made claims against the Chachapoyas and, in particular, how Guaman Poma traveled twice to Lima, on 10 September 1597 and again on 6 March 1599, to appear before the Royal Audiencia. In both instances, he came back to Huamanga 
armed with certified documents upholding his land titles (Prado Tello and Prado Prado 1991:339, 375). He was clearly the most persistent of Jauli's antagonists as well as the most successful. Domingo Jauli evidently was able to triumph over him only by successfully convincing the authorities that Guaman Poma was an interloper-not an authentic but rather a fraudulent representative of the clan whose legal claims the highest court in the land had upheld. Removing him must have been tantamount to nullifying those claims.

\section{Chupas and the Chachapoyas in the Nueva corónica $y$ buen gobierno}

Guaman Poma does not tell the sad story of his legal defeat at the hands of the Chachapoyas in the Nueva corónica y buen gobierno, but he $(1980: 857,871,994)$ does decry their freedom from tribute payment and personal service, for which he argues they should be responsible "even if they have official duties," alluding to their role in law enforcement. Guaman Poma otherwise refrains from mentioning the elite status they enjoyed. He asserts, on the contrary, that they were known as incorrigible rebels against Inca domination and as tricksters and thieves-an earned reputation, he says, that continued into contemporary times (Guaman Poma 1980:347, 391, 397).

Guaman Poma makes six substantive references to Chupas in the Nueva corónica y buen gobierno. They do not describe his loss of Chupas but rather present the reasons it had rightfully belonged to his clan and, implicitly, why it should still remain so. The first reference appears in the apocryphal letter in the chronicle in which Don Martín Guaman Malqui de Ayala introduces his son to the king. In this complex amalgam, Don Martín is identified as a former minister of the Inca, the lord of the Chinchaysuyo quadrant of the Inca empire, and currently, in the colonial era, lord of the Indians of the province of the encomiendas of Lucanas Andamarca and Soras as well as of the city of Huamanga and, within its jurisdiction, Santa Catalina de Chupas (ibid.:5). Rolled into one are references to at least three temporally distinct roles of social and political affiliation. The core of this ensemble around which Guaman Poma arranges the other titles is his father's identification with Chupas. This becomes evident insofar as the other five substantive references to Don 
Martín Guaman Malqui's activities focus on the role that Guaman Poma assigns to him in the 1542 battle of Chupas. In this military engagement, Vaca de Castro, with the help of Chachapoya forces among others, defeated the forces of the insurgent Diego de Almagro the younger (Hemming 1970:263).

Guaman Poma $(1980: 415,563,750,918,1058)$ mentions the battle of Chupas on various occasions. The most important of these are found in his account of the civil wars among the Spanish after the conquest, in his elliptical reference to the 1600 lawsuit, and in his description of Huamanga in the chapter on the "cities and villas of these kingdoms." In two of these instances, he (ibid.:415, 1058) makes the point that his father, Don Martín de Ayala, and Don Juan Tingo had served the royal forces under Vaca de Castro and that, at that time, they were already in possession of "houses and fields, properties in Santa Catalina de Chupas." By means of this assertion Guaman Poma implicitly argues that his people (not the Chachapoyas) had championed the royal cause with great success and that when they had done so (again, unlike the Chachapoyas) they had been long and permanently established in the area of Chupas where the Chachapoyas were later (and unjustly) granted lands. Even though Domingo Jauli and the Chachapoyas had come to an agreement with the Tingo family (perhaps, as Guaman Poma charged in one of his 1597 petitions, through intimidation and murder of one of their family members), Guaman Poma continued to uphold in the Nueva corónica y buen gobierno the close relationship between the Guaman and Tingo clans as well as their common Huamanga/Chupas heritage.

In writing about the events of the year 1600 in the Nueva corónica $y$ buen gobierno, however, Guaman Poma was more elliptical than prolix. He (ibid.:918) says only that he had been encouraged by the Indians' advocate to file his suit in defense of some lands that were by rights his, from the time of the creation of the earth through that of the most recent state-mandated inspections; he identifies the property as being located in Santa Catalina de Chupas, "where Diego de Almagro the younger fought against the royal crown." We have just seen the Expediente's record of these colonial-era confirmations.

Nevertheless, the link between the criminal conviction of 1600 and the episode he recounts in the chronicle can be deduced through his reference to the battle of Chupas and his mention of the corregidor's deputy Pedro 
de Rivera, before whom Domingo Jauli successfully made his accusations against Guaman Poma's integrity (Zorrilla 1977:59). Guaman Poma frames the elliptical reference to his failed suit with an assertion that he makes repeatedly about having taken up a life of poverty in order to "see and understand the injustices of the world" that had not been revealed to him in his life as a lord (1980:916-918). The allusively referenced Chupas litigation becomes the main argument for his assertion that the pursuit of justice ends up (literally) as "nothing more than a cudgelling." Guaman Poma goes on to tell that his land title had been confirmed by "the judge, licentiate Montalvo," who observed all the boundary markers (mojones, "saywa" in Quechua) established by the Inca Tupac Yupanqui and upheld Guaman Poma's family's title to all the lands, woodlands, and fields that lay within the markers. The list of sites he enumerates in the chronicle is identical to the one he had given in a 1597 petition in the Expediente (Guaman Poma 1980:918; Prado Tello and Prado Prado 1991:337). His family's lawful rights to the areas named had been confirmed on 10 August 1597 and officially entered into the Audiencia's records in Lima on 7 August 1598 (Prado Tello and Prado Prado 1991:332, 337-339).

Guaman Poma's (1980:918) account of Pedro de Rivera's refusal to obey the order identifies the latter, as does the Expediente Prado Tello, as the teniente de corregidor of Huamanga. In the chronicle, Guaman Poma describes Rivera as a "resident of Huamanga and a man who understands nothing of letters and does not even know how to write." Regarding the land survey for which he was accused of failing to appear, Guaman Poma (ibid.:919) says only that Rivera sent out a notary to verify the land claim when it was his own responsibility to do so: "If that was done to me," cries Guaman Poma, "what will they do to the poor people who don't know any better?" He lets his indignation show but predictably reveals nothing about the humiliating sentence that resulted.

Despite his deliberate silence about his legal defeat at the hands of the Chachapoyas, Guaman Poma disparages them throughout the Nueva corónica y buen gobierno in a global characterization that spans Andean history from the time of the Incas through the colonial present. In lengthy passages that embrace the length and breadth of his work, Guaman Poma provides a scathing condemnation of the mortal enemies whose actions sent him (evidently permanently) away from Chupas and Huamanga to the province of Lucanas, more than thirty leagues to the south. 
After being conquered by Huayna Capac, he asserts, the Chachapoyas sowed the seeds of the Inca's doom. One of their women, Rava Ocllo, "mother of many bastard princes" ("auquiconas uastardos"), gave birth to the "bastard prince" Atahualpa (ibid.:113-114, 140, 163-164, 168, 174, 334-335). As immigrants to Huamanga, Guaman Poma (ibid.:269) accuses the Chachapoyas of practicing idolatry and performing sacrifices of "children and gold and silver and clothing, food and objects made of precious metals." He characterizes them as "rebellious Indians and thieves, imposters," for which reason the Inca "never gave them any important posts." On the contrary, he claims, they had been subjects of his grandfather Guaman Chaua, whom the Inca honored with "many posts and offices, privileges in all this kingdom" (ibid.:347). Guaman Poma accuses the Chachapoyas of having been responsible for the death of the legitimate Inca prince Huascar ("they did everything to destroy Huascar Inca and all his progeny so that the legitimate Incas would rule no more") and then becoming outlaws, roaming free, assaulting and terrorizing people on public roads (ibid.:347, 391, 397). His repeated insistence that they pay tribute, serve in the mines, and perform all the personal services to the colonists demanded of other ethnic groups is an aggrieved reference to the official privileges enjoyed by them in Huamanga (ibid.:857, 871, 994).

Most significantly, Guaman Poma makes the Chachapoyas responsible for contributing to the proliferation of the mestizo population. He describes the city of Trujillo as a "land of many mestizos as is the city of the Chachapoyas, where many mestizos and mestizas multiply and the Indians of these provinces languish and disappear and there is no remedy. ... And thus the [race of the] Indians is coming to an end" (ibid.:1026).

\section{Mestizaje in the Nueva corónica y buen gobierno}

Beyond the criticism of his Chachapoya enemies as fomenters of racial mixture, Guaman Poma's resounding condemnation of mestizaje constitutes one of the basic premises of his work's conceptualization. As a treatise on colonial reform (see below, "Writing and Religion: The Visita Report"), his text is shot through with dozens of long, haranguing passages of anti-mestizaje sentiment. The topic plays a key role in the powerful chapters of Guaman Poma's $(1980: 974,984)$ invented dialogue with the king on the subject of colonial reform ("Pregunta su Magestad"), 
as well as in his sweeping chapter of moral "considerations" ("Conzederaciones"). In both, Guaman Poma raises the fundamental issue of how to save Andean Peru from ethnic disintegration and destruction. The principal solution he advocates is the complete segregation of the races in order to avoid two evils: the involuntary and violent impregnation of Andean women by men of other races as well as that occasioned by their voluntary coupling with them (ibid.:524, 530, 536, 539, 542-544, 547, $580)$.

The campaign of anti-mestizo advocacy launched by Guaman Poma as part of his general reform program has several elements. First, he views the mestizo as an exploiter of the Andeans (ibid.:509-510, 551, 552, 553, $555,596,928,983,996)$, an assessment that was also made by the viceroy of Peru, Don Juan de Mendoza y Luna, who left office, as we have seen, around the time Guaman Poma was finishing his work (Mendoza y Luna 1615:f29r). Second, despite the fact that Guaman Poma (1980:14-21) lauds unconditionally the religious devotion of his half-brother who was a mestizo priest, he adamantly condemns the ordination of mestizos to the priesthood. This argument plays a prominent role in his dialogue with the king (ibid.:996), and he censures mestizo priests not merely for moral corruption but, more important, for returning their Andean brethren to the traditional religion of their ancestors (ibid.:902-903). Finally, Guaman Poma attributes to the growth of the mestizo population the disappearance of the Andean race, a sentiment that he expresses in the very last, urgent remarks he pens into his autograph manuscript (ibid.:1138): "And thus the said author has seen very many Indian women prostitutes, burdened with little mestizos and mulattoes, all wearing Spanish finery. Although they be married [to Andeans], they go about with Spaniards and Africans. And thus other [Andean women] do not want to marry Indians or leave the said city because it would mean abandoning their whoring ways.... For this reason the said Indians do not multiply in this kingdom." The sense of urgency and encroaching doom with which Guaman Poma brings his work to a close leads us to reconsider the life experiences that made possible its emergence.

\section{Guaman Poma's Biography Reconsidered}

The Expediente Prado Tello offers the best platform from which to reassess Guaman Poma's life and itinerary. From the vantage point of the 
decade of 1590 , we can look forward and back, Janus-like, to rethink the course and chronology of Guaman Poma's activities. Monica Barnes (1999; personal communications, 11 October 1999 and 20 October 1999) offers such an assessment, and hers is the general outline followed here. The only previous similar account is that of José Varallanos (1979:30 36), who envisioned such a trajectory based on the fragments of the Expediente Prado Tello and the Compulsa Ayacucho then at his disposal. Barnes has considerable knowledge of the geography of Ayacucho, and she agrees that although Varallanos (1979:29-46) started from an incorrect premise regarding Guaman Poma's birthplace, he came to the correct conclusion about Guaman Poma's home territory and his association with Lucanas Andamarca and neighboring areas.

In the present instance my objective is to make visible the links between Guaman Poma's vocational life and literary work. I take the Nueva corónica y buen gobierno not merely as a source of information about his life but, more important, as the means to highlight how the life and the work are reflective of one another. I seek to illustrate this integrity between Guaman Poma's life and work in the final section of this essay. My argument is that Guaman Poma produced the complete, final version of his work as we know it after his exile from Huamanga in 1600, as all the temporal references to events, and the local references to the provinces of Lucanas Andamarca, Soras, and Aymaraes, attest.

The major obstacle in reconstructing Guaman Poma's vital trajectory has been the tendency to begin at the beginning, that is, to attempt to establish his birthplace. Identifying as his home San Cristóbal de Suntunto (Sondondo) in the last chapter he wrote, as well as on the penultimate page of his chronicle, and describing it as a site of familial and local activity, Guaman Poma's testimony itself has inspired the inference that he was born there (Guaman Poma 1980: 745, 833, 1104, 1106, 1188). Additional references to other nearby settlements in the province of Lucanas, such as Concepción de Huayllapampa de Apcara in his father's apocryphal letter in the Nueva corónica and Santiago de Chipao in his own 14 February 1615 letter to the king, have been called in to support the hypothesis (Guaman Poma 1980:7; Lohmann Villena 1945:327). In seeking to establish Guaman Poma's birthplace in Lucanas, Abrahám Padilla Bendezú (1942) was the first to collect and identify the names of local colonial officials, almost all of whom worked in the province of Lucanas (Porras Barrenechea 1948:25; Padilla Bendezú 1979:98-99). 
Seeking, on the contrary, to identify Guaman Poma's birthplace as Huánuco, José Varallanos (1979:22, 38-39) nevertheless identified the names of kurakakuna (local ethnic lords) of the encomiendas of Lucanas Andamarca and Soras who are mentioned in the extirpation of idolatries reports of Cristóbal de Albornoz, the Relaciones geográficas de Indias (1586) reports, and in the Nueva corónica y buen gobierno. The province of Lucanas has thus been frequently identified as Guaman Poma's birthplace and/or residence as an adult.

The decade-long pursuit of the Chupas properties and the claims Guaman Poma made about them in the Expediente Prado Tello strongly suggest that Huamanga was the area Guaman Poma considered "home," even though he may have worked as a colonial Indian administrator in the Lucanas area in the late 1590 s, due to his earlier experience there with Cristóbal de Albornoz (Prado Tello and Prado Prado 1991:338, 360). If we were to suggest a birthplace or at least a parental home for Guaman Poma, it would likely be the area of Chupas. If we have been misled by Guaman Poma's apparent claims in the past, it is not because he gives wrong information or makes up tall tales about his personal experience. Rather, as we have seen ("Chupas and the Chachapoyas in the Nueva corónica y buen gobierno"), he attempts to suppress key information, in particular, his 1600 expulsion from Huamanga.

By his own claim (Guaman Poma 1980:860, 1106), Guaman Poma was born "after the time of the Incas," and he declared himself to be eighty years of age at the time he finished writing his work. The itinerant life and/ or forced resettlements demanded of so many members of his generation (born between the mid-1530s and mid-1550s) suggest that the course of his own was not atypical.

As a mestizo by culture (but not by race), Guaman Poma would have been known as an indio ladino, that is, as someone who was presumably proficient in Castilian, Christian in belief, and Hispanicized in custom (see Adorno 1991a, 1991b). Because of the effective erasure of elite status that its use commonly connotated, the colonialist term indio ladino was never used by Guaman Poma to refer to himself. At the opposite pole of linguistic expertise and practice of Christian customs, the term could refer to values that ran, on a sliding scale, from prudence and sagacity to craftiness and cunning. Guaman Poma surely feels the sting of such negative connotations when he mentions that he and others are scorned 
as "ladinejos" or "santicos ladinejos," that is, as great and impertinent talkers, overzealous converts, and busybodies (Guaman Poma 1980:733, 738 , 796, 838). Guaman Poma claims to have learned reading and writing in Spanish from the mestizo priest Martín de Ayala, whom he identifies as his half-brother and whose piety he celebrates (ibid.:17-21). As Guaman Poma's views on mestizaje reveal (see above, "Mestizaje in the Nueva corónica"), his admiration for this half-brother is the exception and not the rule of his assessment of mestizo clergy.

Guaman Poma's activities first come into view for the period of the 1560 s through the early 1580 s, although for this period they are known only on the basis of inferences drawn from his work. After the civil wars among the Spanish, his earliest reference to colonial affairs is Damián de la Bandera's 1557 general inspection tour. Guaman Poma (1980:410) calls it "the first general inspection of the Indians of this kingdom," but its scope was the province of Huamanga (Jiménez de la Espada [188197] 1965:176-180). He illustrates a typical census event in which the inspector Bandera asks the mother of a young boy to identify her son. She responds in Quechua that the child, who is her own, is the son of a powerful lord (Guaman Poma 1980:410). The vividness of this Huamanga census encounter serves as a clue that Guaman Poma and his own family lived there at the time, and that the same questions would have been put to them.

Subsequent to this probable youthful recollection, Guaman Poma writes of having served the ecclesiastical inspector (visitador) Cristóbal de Albornoz in the identification and punishment of practitioners of traditional Andean religion. It is likely that Guaman Poma was recruited in Huamanga for Albornoz's 1568-1570 campaign to the provinces of Soras, Lucanas Laramati, and Lucanas Andamarca (Varallanos 1979:31; Barnes, personal communication, 20 October 1999). The names of inspection team personnel who appear only in Albornoz's reports from this specific tour, as well as the names of local Andeans punished, are repeated in the Nueva corónica y buen gobierno. My comparison of Albornoz's reports and Guaman Poma's chronicle shows that, of the twenty-five witnesses brought by Albornoz in his "Información de servicios" of 1570, Guaman Poma (1980:20, 430-441, 481, 573, 742, 748) names six of them: Antonio de Oré, Juan [Alonso] Palomino, Pedro del Prado, Captain Cristóbal Peña, Captain Francisco de Cárdenas, and 
Pedro de Contreras (see Millones 1990:67, 81, 84, 87, 93, 111, 156). Guaman Poma praises Peña, Palomino, and Cárdenas for charity toward the Indians, cites Contreras for cruelty toward them, and describes Oré (the encomendero to whom he refers by his son's name, [Luis] Jerónimo) as being "very Christian" but whose Indians nevertheless "had many complaints" (Guaman Poma 1980:20, 573, 742, 748).

Taking into account several areas in the province of Lucanas Andamarca, Albornoz's 1584 "Relación de la visita de extirpación de idolatrías" lists the names of several kurakas, including Don Juan Guancarilla, the Mullo Guamanis, the Pilconis, and Francisco Uscar Paucar, which Guaman Poma later repeats in the Nueva corónica y buen gobierno (Millones 1990:284, 286-290, 292, 294, 295; Guaman Poma 1980:499, 602, 792, 1107). The same kurakas are named in the 1586 report on the Lucanas Andamarca encomienda in the Relaciones geográficas de Indias (Jiménez de la Espada [1881-97] 1965:237).

Albornoz's extirpation of idolatries campaigns probably provided Guaman Poma's earliest significant experience with the policies and practices of the missionary church in native Andean communities. He expresses approval of the work carried out by Albornoz and points out that Albornoz punished the practitioners of Taki Unquy (Guaman Poma 1980:282, 690). Albornoz has been broadly credited for the suppression of this radical nativist movement, which preached the triumph of Andean gods over the Christian, advocated rejection of all that was European, and coincided with the threat of armed rebellion against the Spaniards from the neo-Inca stronghold at Vilcabamba. Guaman Poma's reference to the practitioners of Taki Unquy as "false shamans" ("hechiceros falsos") suggests that he viewed its current leaders as exploiting traditional rituals, which in Inca times had been mounted for the expulsion of sicknesses, for their own personal and/or political gain (Adorno 1991a:239-241).

The 1570 s are vividly represented in the Nueva corónica y buen gobierno by Guaman Poma's recollections of Cuzco and the administration of the viceroy Francisco de Toledo (1569-1581). The first years of Toledo's regime in particular seem to have constituted for Guaman Poma one of the most significant periods of colonial affairs with which he was familiar, and he registers as the most permanent economic and social effects of the Toledo years the systematic census-taking and one of its consequences, the reducciones, whereby native communities were removed from their traditional homelands and relocated in order to serve 
colonial needs for native labor. Guaman Poma provides an extensive account of the legislation promulgated by Toledo in Cuzco (Guaman Poma 1980:448-450) and examines Toledo's general inspection tour of the viceroyalty.

Guaman Poma points out that the tour was carried out, with different inspectors assigned to different provinces, after the resettlement program had been undertaken. He then names two of the inspectors appointed for the province of Huamanga, Jerónimo de Silva and Rodrigo Cantos de Andrada, again revealing that Huamanga was the locus of his close acquaintance and, no doubt, the sphere of his activity (Romero 1921:122). He picks up in Huamanga the thread of Toledo's late 1570 journey from Lima to Cuzco, and he reports events of the subsequent journey to Cuzco as an observer and participant. He notes Toledo's reception in the city of Huamanga and recalls the highly theatrical and symbolic act that Toledo carried out at the Inca site of Vilcashuaman on the stone step pyramid from which the Inca had presided over his court (Hemming 1970: 105). Guaman Poma describes Toledo ascending the grades to the Inca's seat (usnu) and being "received like the Inca himself by all the principal lords." Guaman Poma adds that Toledo then commanded the oldest and most high-ranked lord present, Don Alonso Naccha [H]uarcaya, now of the pueblo of San Pedro de Queca in the province of Lucanas Andamarca, to ascend to the top of the monument (Guaman Poma 1980:447).

As though he were an officer of Toledo's inspection tour, Guaman Poma later provides a modified version of a visita-style report. He names himself("Don Phelipe de Ayala, prince, author of this said chronicle") as its author, thus honoring the tradition of governmental service he attributes to his ancestors. He sets forth an exposition of the characteristic visita report themes, namely, the standard topics of the forms of local or regional governance and succession (Guaman Poma 1980:454-459; see Jiménez de la Espada [1881-97] 1965: 176-180).

Guaman Poma recollects most vividly the execution of the Inca prince Tupac Amaru. He recalls in detail the skirmish enacted in Cuzco's Plaza de San Francisco by the Spanish military party prior to its departure for Vilcabamba to capture the surviving Inca (Guaman Poma 1980:447). Guaman Poma portrays with considerable drama Tupac Amaru's 1572 entrance into the ancient Inca capital as a prisoner and his subsequent execution and burial. As if he had been an eyewitness to those events, he pictures the powerful scene of the Andean women's mourning and he 
lauds the bishop of Cuzco, Sebastián de Lartaún (1573-83), for his condemnation of the execution (ibid.:451-454).

Guaman Poma's principal recollections from the early 1580 s concern the activities of the church. His familiarity with the provincial church councils held in Lima for the purpose of establishing and refining policies for the proselytization of the Andean peoples is considerable (ibid.:232, $528,579,585,586,600,604,612,654,656,665,674,679,693,701,702$, $892,895,1089$ ), and his enthusiastic support of its decrees on a broad range of issues reveals his orthodox views on the need for rigorous and thorough evangelization.

Given his complete familiarity with the conciliar edicts, Guaman Poma may possibly have been in Lima when the Third Church Council was convened there in 1582-83. Although he mentions some of the churchmen who participated (one of its principal theologians, the Jesuit José de Acosta; the Franciscan from Huamanga, Luis Jerónimo de Oré; and the secular priest Miguel Cabello Balboa), his references to them are as authors of the books they wrote. The question remains open as to whether his contact with these churchmen was as a reader of their works or as an observer and informant at the Council itself. His praise of the Jesuits, for example, may reflect his indirect acquaintance with the prominent role they played in the Council (Adorno 1978:140, 148-150). As Xavier Albó (1998:339) has observed, Guaman Poma mentions only two Jesuits by name in the course of his entire work, which indicates that he probably knew few of them personally. The priests who populate Guaman Poma's chronicle are overwhelmingly those who served in local Andean parishes in the provinces of Lucanas Andamarca, Soras, and Aymaraes.

The portion of Guaman Poma's life best known from external sources is the six-year period from 1594 to 1600 . During this decade Guaman Poma was serving as an interpreter and witness in proceedings in Huamanga that confirmed land titles and implemented the policies resulting from Toledo's reducciones (see above, "Guaman Poma in the Documentary Record"). At the same time, he was defending the land interests of himself and his kin in the valley of Chupas (see above, "Guaman Poma in the 1590s" and following subsections). Losing these legal battles and acknowledging them only allusively in the Nueva corónica y buen gobierno, Guaman Poma $(1980: 886,918)$ nevertheless 
lets slip the observation, in discussing the pretensions and criminal activities of "common Indians," that he first became aware of such social disintegration-Andean society being turned "upside-down"when he began his travels, that is, "in the year that we left, of $160[0]$ and afterward."

References to Guaman Poma's activities in the years subsequent to 1600 are found in his 14 February 1615 letter to Philip III as well as in the Nueva corónica y buen gobierno. As Porras Barrenechea (1948:25, 30) first observed, most of Guaman Poma's experience was probably limited to the region of the colonial city of Huamanga and the province, more than thirty leagues to the south, of Lucanas; his trips to Lima would take him via Huancayo or Nazca and Ica. The twenty-odd settlements and the majority of local colonial officials whom he names in this period-the Buen gobierno is suffused with these myriad references - are from the province of Lucanas (Porras Barrenechea 1948:25, 31, 31n19; Padilla Bendezú 1942, 1979). Guaman Poma's references to local events span the years from 1608 to 1615 , and he makes several references to noteworthy occurrences of the years 1611,1612 , and 1613. For example, Guaman Poma refers at length to past events such as the inspection of the local priests and parishes in Lucanas as part of a general inspection tour carried out in 1611 (1980:693, 704, 944). He (ibid.:944) details how he was imprisoned at that time for seeking to defend the local Andean citizenry whom he represented as an appointee of the colonial administration.

From all this we infer, as José Varallanos (1979:33) and more recently Monica Barnes have suggested, that once forced into exile from Huamanga at the end of 1600, Guaman Poma went south to the province of Lucanas Andamarca. Barnes (personal communication, 20 October 1999) points out the logic of this choice, given that Guaman Poma was already familiar with that area since he had accompanied Cristóbal de Albornoz on his inspection tours to Soras and Lucanas (and had also served the colonial administration there). The exile that Guaman Poma suffered was clearly that from Huamanga in 1600, not, as Porras Barrenechea (1948:33) and Padilla Bendezú (1979:171) earlier postulated, from San Cristóbal de Suntunto in the 1590 s, which was a hypothesis based ultimately on Suntunto's being considered Guaman Poma's birthplace and site of traditional land holdings. 
Guaman Poma claimed acquaintance, as noted above, with Don Luis de Velasco, whose tenure as viceroy of Peru he dated correctly as 15961604 and whose status he identified in the current year of 1615 as holder of the office of the presidency of the Council of the Indies and bearer of the title of the marquisate of Salinas (Philip III had granted Velasco the title in 1609)(Guaman Poma 1980:470-471; Porras Barrenechea 1948:75; Varallanos 1979:34; Padilla Bendezú 1979:12). This contact with the viceroy's court may have been initiated through Guaman Poma's appearances before the Royal Audiencia in the late 1590s, but it is more likely, as Porras Barrenechea (1948:33) earlier suggested, that it occurred (or was fully developed) later.

Porras Barrenechea marks the year as 1600 or 1601 because of the specific remarks Guaman Poma makes about Velasco's governance. In particular, Guaman Poma (1980:831-832) tells of having informed the viceroy about the obstacles presented by colonial officials to Indians' presentation of formal written grievances against the administration, and, he writes, Velasco responded by levying a fine of one hundred pesos on corregidores for failure to comply with, or for subverting, native's requests. Velasco, in fact, instituted this fine in his ordinances for corregidores of 31 July 1601. This action, plus Guaman Poma's personalized portrait of the viceroy (unlike the generic ones of his peers), showing him wearing eyeglasses, confirms Guaman Poma's acquaintance with Velasco's "house of good government" (Porras Barrenechea 1948:33). Such specific references and their confirmation suggest that Guaman Poma's (1980:715) assertions about his vocational activities were correct.

Since he refers to his extreme old age in "Camina el autor," modifying his original entry for his age from seventy-eight to eighty years (Guaman Poma 1980:1106; Porras Barrenechea 1948:74), it is fair to assume the existence of a significant interval between the time of his preparation of this particular text and his final pass over it. Since the last event Guaman Poma mentions by year is the December 1615 conclusion of the Marqués de Montesclaros's tenure in office as viceroy, it is clear that Guaman Poma made his last pass over the manuscript after the end of that year. In any case, 1615 is the final year for which we have any authenticated written record by, or about, Felipe Guaman Poma.

Overall, noting the frequency with which Guaman Poma's observa- 
tions about particular events are detailed enough to suggest his personal participation, finding his assertions about particular people and events confirmed by independent, external documentation, and perceiving the thoroughness with which he documents civil and ecclesiastical affairs in the province of Lucanas after the year 1600, we have significant accumulated evidence regarding substantial portions of Guaman Poma's life. Hence his remarks (1980:715) about being reared in the "palace and house of good government and the Audiencia," serving the officials of church and state, seeing civil and church inspectors at work, and participating in inspection tours as well as hearings of land title confirmation, all and altogether represent a fair summary of his lifelong activities. Furthermore, the perspectives Guaman Poma developed in these pursuits permeate the entire work and give it its shape, texture, and meaning. The integration of Guaman Poma's activities with the work he produced is self-evident, and it can be demonstrated best by considering the ways in which his writing is given shape and substance by the experience of his early adult years in service to the colonial church.

\section{Writing and Religion: The Visita Report}

In chapter 3, I examine Guaman Poma's readings of the bi- and trilingual catechisms and collections of sermons as well as the didactic/ devotional works of Fray Luis de Granada and other "doctors of the church." My aim is to elucidate how Guaman Poma utilized and modified them in forming his own arguments for political, social, and clerical reform. A less bookish dimension of Guaman Poma's engagement with the colonial church and its practices also pertains to the development of his literate life. This is his work on inspection tours, and he does not shrink from expressing pride at having worked for civil and church inspectors, "serving as an interpreter and conversing, inquiring of the poor Spaniards and the poor Indians and the poor African blacks" (Guaman Poma 1980:715). The types of information gathered in the inspection tour permeate every part of his work. In coordination with his book learning, the ecclesiastical inspection tour provides a comprehensive model or guide for Guaman Poma's writing.

The twin pillars of any visita report are review and reform, that is, the description of the current situation in its particulars and recommenda- 
tions for the resolution of problems cited. Guaman Poma (ibid.:1) conforms to this general scheme in announcing that his chronicle will be useful for reforming the lives of Christians and infidels, Indians, encomenderos, corregidores, priests, miners, caciques and other ranks of the native administrative hierarchy as well as for "common Indians and other Spaniards and persons." It will also be useful, he says, for general inspection tours of church and state and the investigations carried out at the end of an official's term of office (residencia). He proceeds through the body of each chapter, outlining social ills and ending with a "prologue" that offers concrete recommendations for reform usually accompanied by spiritual admonitions. We have seen above ("Mestizaje in the Nueva corónica") how Guaman Poma, from his reformist's perspective, handles the problem of mestizaje.

Guaman Poma's emphasis on correction and reform is everywhere evident. Hence he utilizes the precepts of the provincial church councils as the authority by which to advocate his program of goals. These include: (1) fomenting literacy among the Andean people, (2) examining and reforming the conduct of the Christian missionary clergy, (3) achieving and maintaining the segregation of Andean communities from those of the colonizing groups, (4) prohibiting mestizos and mulattoes from residing in Andean communities, and (5) successfully separating the practitioners of Andean cults from their communities and the rest of the Andean population so that "that which the ministers of God spend a year building be not destroyed in a single day" (Bartra 1982:80, 153, 154, 168). Guaman Poma reiterates the need for these measures in countless instances throughout his work, and he returns to them in the final additions to the completed text, reiterating the urgent need for reform by the missionary clergy as well as the eradication of traditional Andean religious and ritual practices (Guaman Poma 1980:241, 691, 857, 869, 876-877; Adorno 1979-80:17-18, 27nn11-13; Adorno 1980:xxxiiixlvi; Adorno 1989:64-70).

On the question of native religion in particular, Guaman Poma's activities as an informant and aide to ecclesiastical officials fomented in him a zealous, negative attitiude toward traditional native spiritual practices that is reflected throughout the work. He sustains this imperative even while adding the final touches to his manuscript. In these urgent, last-minute corrections and additions Guaman Poma continues to insist upon the necessity of suppressing traditional rituals, such as the ruthuchiku 
and warachiku, respectively, the life-cycle ceremonies of the first cutting of the hair and the investiture of breeches, for the (Christian) betterment and well-being of Andean society (1980:241; see also 285, 585, 615, 791, 795, 907).

The organization of major portions of the Nueva corónica, especially the chapters devoted to the inspection tour of Tupac Inca Yupanqui and the description of the age-grades of Andean society, reproduce the format of the inspection tour report (ibid.:184-236). All the chapters that deal with ancient Andean religious and ritual practices are materials at least in part gathered, as Guaman Poma (ibid.:285) himself declares, on the tour(s) of inspection on which he accompanied Cristóbal de Albornoz.

In its entirety, the Buen gobierno (two-thirds of the work) is presented as a visita report in which the colonizers are grouped together according to occupational and racial groups (from Spanish miners to African slaves) and the Andeans are presented in categories defined by their inherited social rank (lords and common Indians) and traditional and/or colonial administrative offices. Within each chapter, the same preoccupations for the realization of "good government," that is, for Christian conduct and the punishment of crimes and abuses, reproduce the protocols of the visita account with its prescriptive advice and recommendations. His final chapter, "Camina el autor," frames for the last time the itinerant inspection tour, as he narrates his journey from site to site and details, settlement by settlement in the area of Huarochiri, the havoc wreaked by Francisco de Ávila's extirpation of idolatries campaign.

Although Guaman Poma criticizes sharply the comportment of church inspectors in his short chapter devoted to them as well as his ringing condemnation of Ávila, he does not advocate the abolition of the institution (see Duviols 1984). On the contrary, he recommends, in one of the final notes added to his work, that their jurisdiction be expanded to include the review of the conduct of the parish priests themselves (Guaman Poma 1980:691). He elsewhere recommends the expansion of the inspection tour team to include an acculturated Indian (indio ladino) to serve in each settlement as the permanent official of the itinerant inspections: "[I recommend that] there be in every settlement a Christian indio ladino and, if possible, that all those who are Christian and ladino serve as inspectors of the priests and corregidores, encomenderos, caciques, and lower-ranked Indian administrators in the said settlements so that there be no stealing or roguery, and so that the Indians do not 
worship idols or get drunk or kill one another and so that the aforementioned Christian [ladino] can inform the justice officials of all of the above for the service of God in this kingdom" (ibid.:903).

Guaman Poma's position with regard to the need to abolish and root out traditional beliefs and practices, as well as to impose a program of complete and orthodox religious instruction to evangelize the Andean population, are hallmarks of his work and are consistently expressed throughout the Nueva corónica y buen gobierno (see Adorno 1991a, 1991b). Together with his militant defense of the need for surveillance of the Andean communities and his detailed exposition of all the prohibited practices that survive in his day in the provinces of Lucanas Andamarca and Soras, Guaman Poma's religious perspective is orthodox and inflexible - in no way syncretic or ambiguous - and it reflects the outlook he must have developed in his youth or early adulthood, accompanying Cristóbal de Albornoz on his inspection tours. It is the integrity he feels between himself and the values of the colonial church that permits him to criticize as well as to praise it so roundly (Adorno 1991a:243-252).

\section{An Anticipated Glimpse into the Artist's Studio}

The other dimension of Guaman Poma's apprenticeship with the ecclesiastical community is his art and its relationship to that of Martin de Murúa's chronicles. The Loyola manuscript of Murúa's 1590 history of the Incas is an essential link in that chain, and, although it had been edited and published in 1922-25 by Horacio H. Urteaga and Carlos A. Romero and in 1946 in separate editions by Raúl Porras Barrenechea and the Reverend Constantino Bayle (Ballesteros Gaibrois 1986:14-16), the manuscript itself subsequently dropped out of sight. Thanks to the success of the decades-long search for it by Juan Ossio, we are at the threshold of the full, documented reconstruction of Guaman Poma's artistic relationship with that of the Murúa chronicles.

Guaman Poma (1980:525, 625, 661-663, 920) refers to Murúa for his activity in the pueblo of Yanaca and his service as parish priest of the pueblos of "Poco Uanca, Pacica, Pichiua" in the province of Aymaraes, located in the present-day Department of Apurimac nearly due east from the clustered pueblos of San Cristóbal de Suntunto, Concepción de Huayllapampa de Apcara, and Santiago (San Pedro) de Chipao in the 
province of Lucanas. According to Ossio (1999), Guaman Poma's (1980:662,743) repeated mention of the captain Alonso de Medina, who was the corregidor and chief judicial official of the province of Aymaraes between 1604 and 1606, indicates that this contact occurred during that time. Guaman Poma's (ibid.:661-663, 795) detailed account of Murúa's conflicts with the local native community suggests a sustained contact, and Guaman Poma's discussion of local Andean governance in Yanaca and a long list of prohibited traditional customs practiced there also point to his considerable acquaintance with that community. He (ibid.:1090) likewise reveals his intimate knowledge of Murúa's history of the Incas by his criticism of its limitations in ignoring the issues of the Incas' provenance, the legitimacy of their rule, and the causes of their fall (see chapter 2).

Given the familiarity Guaman Poma shows with Murúa's activities and writings, the hoped-for republication of the Loyola manuscript can elucidate significant dimensions of Guaman Poma's artistic achievement and potentially settle the issue of his precise artistic relationship to the work of Murúa. The promise held out by the full study of the Loyola Murúa manuscript is substantial, and together with the recent and ongoing work on Guaman Poma's achievement by Cárdenas Bunsen, Cummins, Fraser, and others, we can anticipate many further significant advances in the study of Guaman Poma, his work, and his world.

\section{Works Cited}

Adorno, Rolena. 1978. "Las otras fuentes de Guaman Poma: sus lecturas castellanas." Histórica 2, no. 2:137-158.

.1979-80. "The Nueva Corónica y Buen Gobierno: A New Look at the Royal Library's Peruvian Treasure." Fund og Forskning 24:7-28.

-1980. "La redacción y enmendación del autógrafo de la Nueva corónica y buen gobierno." In Guaman Poma [1615] 1980:1:xxxii-xlvi.

- 1989. Cronista y principe: La obra de Don Felipe Guaman Poma de Ayala. Lima: Pontificia Universidad Católica del Perú.

. 1991a. "Images of Indios Ladinos in Early Colonial Peru." In Andrien and Adorno, eds., 1991:232-270.

1991b. "La visión del visitador y el indio ladino." In Cultures et sociétés: Andes et Méso-Amérique. Mélanges en hommage à Pierre Duviols, 
edited by Raquel Thiercelin, vol. 1, pp. 35-50. Provence: Université de Provence.

- 1992. "Colonial Reform or Utopia? Guaman Poma's Empire of the Four

Parts of the World." In Amerindian Images and the Legacy of Columbus, Hispanic Issues 9, edited by René Jara and Nicholas Spadaccini, pp. 346-374. Minneapolis: University of Minnesota Press.

- 1993. "The Genesis of Felipe Guaman Poma de Ayala's Nueva corónica y buen gobierno." Colonial Latin American Review 2, nos. 1-2:53-92.

Adorno, Rolena, Mercedes López-Baralt, Tom Cummins, John V. Murra, Teresa Gisbert, and Maarten van der Guchte. 1992. Guaman Poma de Ayala: The Colonial Art of an Andean Author. New York: Americas Society.

Albó, Xavier. 1998. "La Nueva corónica y buen gobierno: ¿obra de Guaman Poma o de jesuitas?" Anthropologica 16:307-348.

Albó, Xavier, and Félix Layme. 1993. "Los textos aymaras de Waman Puma."

In Religions des Andes et langues indigènes, Actes du Colloque III d'Études Andines, coordinated by Pierre Duviols, vol. 1, pp. 13-42. Provence: Centre Aixois de Recherches Latino-Américaines, Université de Provence.

Alfonso X el Sabio. [1263] 1587. Siete partidas. Valladolid: Diego Fernández de Córdoba.

Andrien, Kenneth J., and Rolena Adorno, eds. 1991. Transatlantic Encounters: Europeans and Andeans in the Sixteenth Century. Berkeley and Los Angeles: University of California Press.

Ballesteros Gaibrois, Manuel. 1978-79. "Relación entre Fray Martín de Murúa y Felipe Huamán Poma de Ayala." In Amerikanistische Studien: Festschrift für Hermann Trimborn = Estudios americanistas: Libro jubilar en homenaje a Hermann Trimborn, edited by Roswith Hartman and Udo Oberem, vol. 1, pp. 39-47. St. Agustin, Germany: Anthropos Institut.

— 1981. "Dos cronistas paralelos: Huamán Poma y Martín de Murúa (confrontación de las series reales gráficas)." Anales de Literatura Hispanoamericana 9, no. 10:15-66.

- 1986. "Introducción." In Historia general del Perú [1611] by Martín de Murúa, edited by Manuel Ballesteros Gaibrois, pp. 5-29. Crónicas de América 35. Madrid: Historia 16.

Barnes, Monica. 1994. "The Gilcrease Inca Portraits and the Historical Tradition of Guaman Poma de Ayala." In Andean Oral Traditions: Discourse and Literature/Tradiciones orales andinas: discurso yliteratura, edited by Margot Beyersdorff and Sabine Dedenbach-Salazar Sáenz, pp. 223-256. Bonner Amerikanistische Studien 24. Bonn: Holos.

1995. "Las edades del hombre y del mundo según Hierónimo Chaves, de Sevilla y Guaman Poma de Ayala, del Perú." In Humanismo siglo XX: estudios dedicados al Dr. Juan Adolfo Vázquez, compiled by Juan Schobinger, 
pp. 291-297. San Juan, Argentina: Universidad Nacional de San Juan.

_. 1999. "La Nueva corónica y buen gobierno fue escrito por un residente de Lucanas." Paper presented at "Guaman Poma de Ayala y Blas Valera: tradición andina e historia colonial," Rome, Italy, 29 September 1999.

Bartra, Enrique T., S.J., ed. 1982. Tercer concilio limense, 1582-1583. Lima: Facultad Pontificia y Civil de Teología.

Bonifaz, Miguel. 1955. Derecho indiano: derecho castellano, derecho precolombiano, derecho colonial. Oruro, Bolivia: Universidad Técnica.

Cárdenas Bunsen, José Alejandro. 1998. "La redacción de la Nueva corónica y buen gobierno." Tesis de licenciatura. Lima: Pontificia Universidad Católica del Perú.

Cieza de León, Pedro de. [1553] 1985. Crónica del Perú: segunda parte, edited by Francesca Cantu. Lima: Pontificia Universidad Católica del Perú y Academia Nacional de la Historia.

Cobo, Bernabé. [1653] 1979. History of the Inca Empire, edited and translated by Roland Hamilton. Austin: University of Texas Press.

Cummins, Thomas B. F. 1992. "The Uncomfortable Image: Pictures and Words in the Nueva corónica i buen gobierno." In R. Adorno et al. 1992: 46-59. . 1993. "La representación en el siglo XVI: La imagen colonial del Inca." In Mito y simbolismo en los Andes: La figura y la palabra, compiled by Henrique Urbano, pp. 87-136. Cuzco: Centro de Estudios Regionales Andinos "Bartolomé de las Casas."

- 1997. "Images on Objects: The Object of Imagery in Colonial Native Peru as Seen through Guaman Poma's Nueva Corónica i Buen Gobierno." Special Issue of Journal of the Steward Anthropological Society 25, nos. 1 and 2:237-273.

Duviols, Pierre. 1980. "Periodización y política: la historia prehispánica del Perú según Guaman Poma de Ayala." Bulletin de l'Institut Français d'Etudes Andines 9, nos. 3-4:1-18.

- 1984. "Albornoz y el espacio ritual andino prehispánico." Revista Andina 2, no. 1:169-222.

Fleming, David. 1994. "Guaman Poma, Hieronymo de Chaves and the Kings of Persia." Latin American Indian Literatures Journal 10, no. 1:46-60.

Fraser, Valerie. 1996. "The Artistry of Guaman Poma." RES 29/30:269-289.

Gisbert, Teresa. 1992. "The Artistic World of Felipe Guaman Poma." In Rolena Adorno et al. 1992: 75-91.

Guaman Poma de Ayala, Felipe. 1615. El primer nueva corónica y buen gobierno [1615]. G.K.S. 2232, $4^{\circ}$. Copenhagen: Royal Library of Denmark. - [1615] 1936. Nueva corónica y buen gobierno. Codex péruvien illustré. Travaux et mémoires de l'Institut d'Ethnologie 23. Paris: Institut d'Ethnologie, Université de Paris. 
[1615] 1980. El primer nueva corónica y buen gobierno [1615], edited by John V. Murra and Rolena Adorno, Quechua translations by Jorge L. Urioste. 3 vols. Mexico City: Siglo Veintiuno.

- [1615] 1993. Nueva corónica y buen gobierno [1615], edited by Franklin Pease G.Y., Quechua vocabulary and translations by Jan Szeminski. 3 vols. Lima: Fondo de Cultura Económica.

Guillén Guillén, Edmundo. 1969. "El cronista don Felipe Guaman Poma y los manuscritos hallados en el pueblo de Chiara." Amaru, revista de artes $y$ ciencias 10:89-92.

Hemming, John. 1970. The Conquest of the Incas. San Diego: Harcourt, Brace, Inc.

Husson, Jean-Philippe. 1985. La poesie quechua dans la chronique de Felipe Waman Puma de Ayala: de l'art lyrique aux chants et danses populaires. Série ethnolinguistique amérindienne. Paris: L'Harmattan.

_. 1995. "En busca de las fuentes indígenas de Waman Puma de Ayala. Las raices incas y yaruwillka del cronista indio: ¿invención o realidad?" Histórica 19, no. 1:29-71.

Imbelloni, José. 1944. "La tradición peruana de las cuatro edades del mundo en una obra rarísima impresa en Lima en el año 1630." Anales de arqueología y etnología 5:55-94.

Jiménez de la Espada, Marcos, ed. [1881-97] 1965. Relaciones geográficas de Indias: Perú [1586], edited by José Urbano Martínez Cabreras. Biblioteca de Autores Españoles 183. Madrid: Atlas.

Kongelige Biblioteks arkiv. 1930-31. Journalsager.

Larson, Brooke. 1988. Colonialism and Agrarian Transformation in Bolivia: Cochabamba, 1550-1900. Princeton: Princeton University Press.

Lohmann Villena, Guillermo. 1945. "Una carta inédita de Huamán Poma de Ayala." Revista de Indias 20:325-327.

López-Baralt, Mercedes. 1988. Icono y conquista: Guaman Poma de Ayala. Madrid: Hiperion.

- 1992. "From Looking to Seeing: The Image as Text and the Author as Artist." In R. Adorno et al. 1992: 14-31. New York: Americas Society.

- 1993. Guaman Poma, autor y artista. Lima: Pontificia Universidad Católica del Perú.

Macera, Pablo. 1991. "Introducción." In Prado Tello and Prado Prado, eds. 1991: 23-80.

Mañaricúa, Pedro [Mínimus, pseud.]. 1955. "Documentos importantes sobre la vida y andanzas del famoso don Felipe Huaman Poma." Huamanga 20, no.85:5-6. Rpt. in Varallanos 1979: 213-214.

Mannheim, Bruce. 1986. "Poetic Form in Guaman Poma's Wariqsa arawi." Amerindia 11:41-67. 
Mendizábal Losack, Emilio. 1961. "Don Phelipe Guaman Poma de Ayala, señor y príncipe, último quellqacamayoq." Revista del Museo Nacional 30: 228330.

1963. "Las dos versiones de Murúa." Revista del Museo Nacional 32: 153-185.

Mendoza y Luna, Juan de [el marqués de Montesclaros]. [1615]. Luz de materias de Indias del Marqués de Montesclaros. Gks 589, 20. Copenhagen: Royal Library of Denmark.

Millones, Luis, ed. 1990. El retorno de las huacas: estudios y documentos sobre el Taqui Onqoy, siglo XVI. Transcripción de los documentos de Cristóbal de Albornoz por Pedro Guibovich Pérez. Lima: Instituto de Estudios Peruanos y Sociedad Peruana de Psicoanálisis.

Murúa, Martín de. [1590] 1946. Historia del origen y genealogía real de los reyes Incas del Perú, ed. Constantino Bayle, Biblioteca missionalia hispánica 2. Madrid: Instituto Santo Toribio de Mogrovejo, Consejo Superior de Investigaciones Científicas.

O’Brien, Pablo. 1996. "Los colores de la historia." Somos (El Comercio, Lima) (26 de octubre de 1996):48-50.

Ossio, Juan M. 1970. The Idea of History in Felipe Guaman Poma de Ayala. B. Litt. thesis. Oxford: Oxford University.

- 1973. "Guaman Poma: Nueva corónica o carta al rey. Un intento de aproximación a las categorías del pensamiento andino." In Ideología mesiánica del mundo andino, edited by Juan M. Ossio, pp. 155-213. Lima: Biblioteca de Antropología.

- 1977. "Myth and History: The Seventeenth-Century Chronicle of Guaman Poma de Ayala." In Text and Context: The Social Anthropology of Tradition, edited by Ravindra K. Jain, pp. 51-93. Philadelphia: Institute for the History of Human Issues.

. 1998. "Research Note: El original del manuscrito Loyola de Fray Martín de Murúa." Colonial Latin American Review 7(2):271-278.

1999. "Semejanzas y diferencias entre las crónicas de Guaman Poma y Murúa." Paper presented at "Primer congreso internacional de peruanistas en el extranjero," Harvard University, Cambridge, Mass., 29 April 1999.

Padilla Bendezú, Abrahám. 1942. "Noticias biográficas de Waman Puma." Alpha 2, no. 2.

1979. Huamán Poma, el indio cronista dibujante. Mexico City: Fondo de Cultura Económica.

Pease G.Y., Franklin. 1995. Los crónicas y los Andes. Lima: Fondo de Cultura Económica.

Pereyra Chávez, Nelson. 1997. "Un documento sobre Guaman Poma de Ayala existente en el Archivo Departamental de Ayacucho." Histórica 21, no. 2:261-270. 
Pietschmann, Richard. [1908] 1936. "Nueva corónica y buen gobierno de Don Felipe Guaman Poma de Ayala." In Guaman Poma 1936: vii-xxviii.

Plas, Sophie. 1996. "Une source européenne de la Nueva corónica y buen gobierno de Guaman Poma." Journal de la Société des Américanistes 82:97116.

Porras Barrenechea, Raúl. 1948. El cronista indio Felipe Huamán Poma de Ayala. Lima: Editorial Lumen.

Prado Tello, Elías. 1952. "Retrazos de la historia de Huamanga: Episodios de la vida de D. Felipe Guaman Poma de Ayala, célebre cronista ayacuchano." In El Estandarte Católico, año 51, no. 1295 (15 de octubre de 1952). Rpt. in Varallanos 1979: 211-212.

- 1954. "En que se refiere a Don Juan Tingo y se nombra a Don Felipe Guaman Poma." El Estandarte Católico, año 53, no. 1331 (30 de abril de 1954). Rpt. in Varallanos 1979: 214.

Prado Tello, Elías, and Alfredo Prado Prado, eds. 1991. Phelipe Guaman Poma de Ayala: Y no ay [sic] rremedio . . . . Lima: Centro de Investigación y Promoción Amazónica.

Romero, Carlos A., ed. 1921. "Libro de la visita general del virrey Don Francisco de Toledo, 1570-75." Revista Histórica 7: 113-216.

Salazar, Rodolfo. "Pieza de un expediente de la comunidad de indígenas de Quinua." In Varallanos 1979: 210-211.

Salomon, Frank. 1986. Native Lords of Quito in the Age of the Incas: The Political Economy of North Andean Chiefdoms. Cambridge, England: Cambridge University Press.

- 1999. "Testimonies: The Making and Reading of Native South American Historical Sources." In Cambridge History of the Native Peoples of The Americas. Part 3: South America, edited by Frank Salomon and Stuart Schwartz, pp. 19-95. New York: Cambridge University Press.

Spalding, Karen. 1984. Huarochiri: An Andean Society under Colonial Rule. Stanford: Stanford University Press.

Stern, Steve J. 1978. "Algunas consideraciones sobre la personalidad histórica de Don Felipe Guaman Poma de Ayala." Histórica 2, no. 2:225-228.

Szeminski, Jan. 1983. "Las generaciones del mundo según don Felipe Guaman Poma de Ayala." Histórica 7, no. 1:69-109.

- 1993. "Idiomas de don Felipe Guaman Poma de Ayala." In Guaman Poma [1615] 1993: 3:9-14.

Urioste, Jorge L. 1980. "Estudio analítico del quechua en la Nueva corónica." In Guaman Poma [1615] 1980: 1:xx-xxxi.

_. 1987. "Los textos quechuas en la obra de Waman Puma." In Guaman Poma [1615] 1987: 1:lxv-lxxvii.

Urton, Gary, with Primitivo Nina Llanos. 1997. The Social Life of Numbers: A 
Quechua Ontology of Numbers and Philosophy of Arithmetic. Austin: University of Texas Press.

Van de Guchte, Maarten. 1992. "Invention and Assimilation: European Engravings as Models for the Drawings of Felipe Guaman Poma de Ayala." In Rolena Adorno et al. 1992: 92-109.

Varallanos, José. 1979. Guaman Poma de Ayala: cronista precursory libertario. Lima: G. Herrera.

Wightman, Ann M. 1990. Indigenous Migration and Social Change: The Forasteros of Cuzco, 1570-1720. Durham, N.C: Duke University Press.

Zorrilla A., Juan C. 1977. "La posesión de Chiara por los indios chachapoyas." Wari 1:49-64.

Zuidema, R. Tom. 1991. "Guaman Poma and the Art of Empire: Toward an Iconography of Inca Royal Dress." In Andrien and Adorno, eds. 1991: 151202.

1994. "Guaman Poma between the Arts of Europe and the Andes." Colonial Latin American Review 3, nos. 1-2:37-85. 
